\title{
Supergénne minerály stratiformnej U-Cu mineralizácie pri Spišskej Teplici (hronikum, Kozie chrbty, východné Slovensko)
}

\section{Supergene minerals of stratiform U-Cu mineralization at Spišská Teplica (Hronicum Unit, Kozie Chrbty Mts., eastern Slovakia)}

\author{
Štefan Ferenc ${ }^{1) *}$, Eva Hoppanová ${ }^{1)}$, Richard KopáčIK(1), Tomáš MIKuš²) a Šımon Budzák ${ }^{3)}$ \\ ${ }^{1)}$ Katedra geografie a geológie, Fakulta prírodných vied, Univerzita Mateja Bela, Tajovského 40, 97401 Banská \\ Bystrica, Slovenská republika; *e-mail: stefan.ferenc@umb.sk \\ 2) Ústav vied o Zemi, Slovenská akadémia vied, Dumbierska 1, 97411 Banská Bystrica, Slovenská republika \\ ${ }^{3)}$ Katedra chémie, Fakulta prírodných vied, Univerzita Mateja Bela, Tajovského 40, 97401 Banská Bystrica, \\ Slovenská republika
}

Ferenc Š, Hoppanová E, KopÁčIK R, Mikuš T, BudzÁK Š (2020) Supergénne minerály stratiformnej U-Cu mineralizácie pri Spišskej Teplici (hronikum, Kozie chrbty, východné Slovensko). Bull Mineral Petrolog 28(2): 295-306 ISSN $2570-7337$

\begin{abstract}
Occurrence of infiltration, stratiform U-Cu mineralization Spišská Teplica - Vápenica-Vysová is located approximately $7.8 \mathrm{~km}$ SW from the district town Poprad and $4.3 \mathrm{~km} \mathrm{SW}$ from the centre of Spišská Teplica village (Slovak Republic). Primary U-Cu mineralization is bound to arkosic sandstones with abundant coalified fragments of higher plants (Kravany Beds, Upper Permian, Hronicum Unit) and consists of uraninite and pyrite. The chalcopyrite and Cu-S mineral phase (digenite?, roxbyite?) form inclusions in clastic fluorapatite and zircon. Among supergene minerals, malachite and goethite are absolutely dominant, azurite, zálesíite and baryte are less represented. Phosphate, probably of the florencite group, and acanthite were only rarely found. Supergene uranyl minerals were not detected. Their lack, or their weak development in all uranium deposits in Kozie Chrbty Mts. can be explained as follows: during the weathering of primary ores, the cation $\mathrm{UO}_{2}{ }^{2+}$ is released from uraninite and coffinite into supergene solutions (uranyl complexes). However, these solutions come into almost immediate contact with fragments of coalified flora (especially in the case of rich $\mathrm{U}$ ores), where $\mathrm{UO}_{2}{ }^{2+}$ binds to the organic uranyl complexes (complexation). Only a relatively small part of uranyl cation escapes from this geochemical trap, and in that case supergene uranium minerals may precipitate.
\end{abstract}

Key words: uranium, copper, malachite, azurite, zálesíite, uranium imobilization, Kozie Chrbty Mts., Western Carpathians

Obdrženo 2. 9. 2020; prijiato 7. 11. 2020

\section{Úvod}

Vo východnej časti Kozích chrbtov - Dúbrave (predtým Vikartovský chrbát) sa nachádza rad malých, historických uránových ložísk (Vikartovce, Kravany, Švábovce, Spišský Štiavnik), ktoré boli vyt’ažené pri prieskume koncom 60. a začiatkom 70. rokov 20. storočia (Tulis, Novotný 1998). Stratiformná, infiltračná U, respektíve U-Cu-Pb mineralizácia, je tu lokalizovaná vo vrchnopermských klastických sedimentoch, ktoré sú obohatené úlomkami zuhol'natenej flóry (kravanské vrstvy; Novotný, Badár 1971).

Okrem vyt’ažených ložísk sa v Dúbrave nachádza tiež niekol'ko indícií a menších výskytov U-Cu mineralizácie, z ktorých je najvýznamnejší rudný výskyt Vápenica - Vysová (názov v zmysle práce Tulis, Novotný 1998) v chotári Spišskej Teplice, ktorého mineralogické pomery neboli doteraz študované. Predložený príspevok je venovaný bližšej mineralogickej charakteristike tohto výskytu, na základe doplneného výskumu Hoppanovej (2020).

\section{Geologická stavba širšieho okolia}

Výrazná morfologická elevácia východnej časti Kozích chrbtov (Dúbrava) je zo S a J zlomovo oddelená od Podtatranskej a Hornádskej kotliny. Hrast' Dúbravy a pril'ahlej časti Hornádskej kotliny (Vikartovská priekopa) sú morfologicky pomerne mladé celky, ktoré sa vytvorili na rozhraní pliocénu a pleistocénu vertikálnymi pohybmi pozdílz V - Z zlomov (Fusán et al. 1963; Maglay et al. 1999).

Horský chrbát Dúbravy je budovaný mladopaleozoickými až vrchnotriasovými horninami tektonickej jednotky hronika (obr. 1). Severne od Vikartoviec a Kravan (oblast' hlavného hrebeňa) vystupuje vulkanosedimentárny komplex vrchnopermského malužinského súvrstvia (Vozárová, Vozár 1988). Klastické sedimenty sú zastúpené hlavne pestrými pieskovcami s polohami červených bridlíc a prachovcov. Na zlomových štruktúrach $v$ pieskovcoch sú lokálne vyvinuté kremenné ( \pm karbonáty, \pm barit) žily s Cu mineralizáciou (Ferenc, Kuruc 2015). Prítomné sú tiež mohutné telesá a dajky bázických až intermediárnych vulkanitov (bazaltoidné andezity, bazalty a ich pyroklasti- 


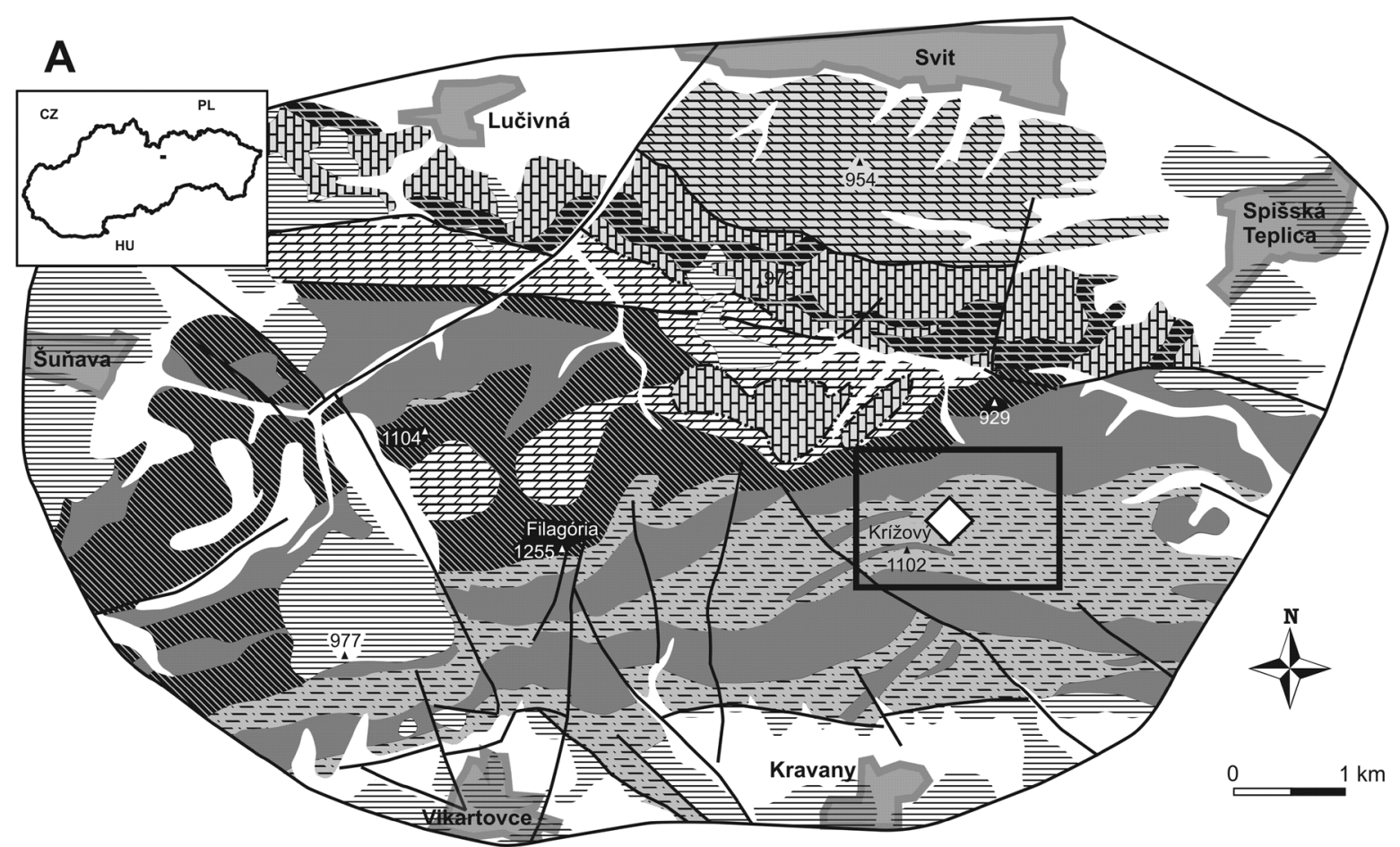

Nerozlíšené sedimenty (kvartér)

Podtatranská skupina:

pieskovce, brekcie, konglomeráty, ílovce (paleogén)

HRONIKUM

hlavné dolomity (vrchný trias)

a) zlomy, b) hranice čiastkových príkrovov

masívne a brekciovité dolomity (stredný - vrchný trias)

sivé ramsauské dolomity (stredný trias)

어ㅍㅐㅐㅐㅐ tmavé gutensteinské vápence (stredný trias)

Bumkovské a Šuňavské súvrstvie:

kremence, bridlice (spodný trias)

Malužinské súvrstvie:

arkózy, pieskovce, konglomeráty, bridlice (perm)

Malužinské súvrstvie:

bazalty, bazaltoidné andezity a ich pyroklastiká (perm)

B

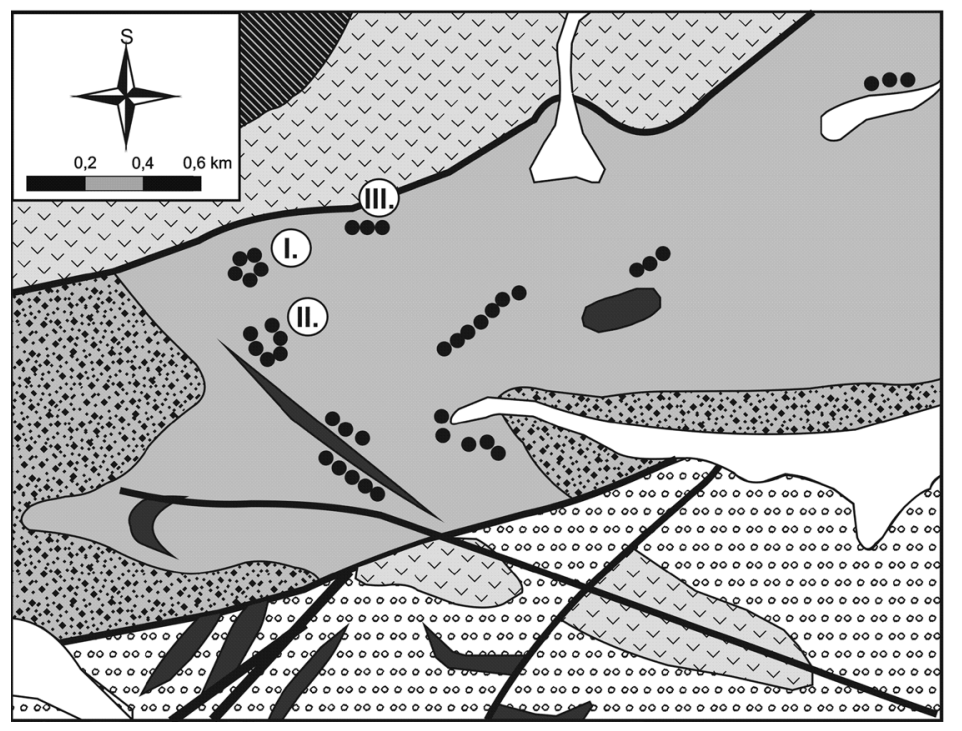

čísla vo vysvetlivkách na obrázku B:

1 - Čiernovážsky vulkanogénny komplex

2 - Vysovské vrstvy

3 - Kravanské vrstvy

4 - Kubašské vrstvy

Spišská Teplica

rudný výskyt Vápenica-Vysová

Obr. 1A) Geologická stavba Kozích chrbtov v území medzi Svitom a Vikartovcami (podla: Biely et al. 1992) s vyznačením študovanej lokality. B) Detailná schéma geologickej stavby rudného výskytu Vápenica - Vysová (podla: Badár, Novotný 1970 in Tulis, Novotný 1998). 
ká), ktoré predstavujú súčast' rozsiahlejšieho kontinentáIneho riftu v pôvodnej vrchnokarbónsko - permskej panve a majú tholeiitický trend (napr. Vozár 1977; Dostal et al. 2003; Vozár et al. 2015). Pre vulkanity je zvlášt' charakteristická $\mathrm{SiO}_{2}$ mineralizácia. $\mathrm{Na}$ viacerých miestach sa v nich vyskytuje aj impregnačná Cu mineralizácia, alebo baritové ( \pm karbonáty, \pm kremeň) žily s Cu zrudnením (Ferenc, Rojkovič 2001; Olšavský, Ferenc 2002).

Nadložie permského vulkanosedimentárneho komplexu tvoria kremence a kremenné arkózy spodnotriasového benkovského súvrstvia (skýt), nad ktorými sa nachádzajú ílovité bridlice a menej rozšírené vápnité pieskovce a vápence spodnotriasového (spat) šuňavského súvrstvia (obr. 1A). Stredný až vrchný trias je zastúpený karbonátovým vývojom (rôzne typy dolomitov a vápencov). Vrchný trias reprezentujú najmä hlavné dolomity s polohami ílovcov a bridlíc lunzského súvrstvia, ktoré budujú masív Baby a Smolníka pri Svite (Biely et al. 1992).

Paleogénne formácie podtatranskej skupiny (Biely et al. 1997) tvoria výplň Podtatranskej a Hornádskej kotliny (obr. 1A). Sú zastúpené dvomi litostratigrafickými jednotkami: borovským súvrstvím (brekcie, zlepence, pieskovce, vápence) a monotónnym hutianskym súvrstvím (prevaha ílovcov).

Kvartérne sedimenty sú reprezentované akumuláciami náplavových kužel'ov pri vyúst'ovaní dolín z Dúbravy do okolitých kotlín. Triasové a paleogénne podložie Popradskej kotliny je z vel'kej miery zakryté akumuláciami glacifluviálnych sedimentov. $V$ údoliach súčasných tokov sa akumulujú sedimenty dolinných nív, v okolí Svitu a Spišskej Teplice sa tiež nachádzajú rašeliniská a menšie výskyty pramenitov (Biely et al. 1997).

\section{Geologická charakteristika študovanej lokality}

Početné rádioaktívne anomálie rudného výskytu Vápenica - Vysová, sa nachádzajú na prilahlých svahoch a dolinkách doliny Vápenica, približne $7.8 \mathrm{~km}$ na JZ od okresného mesta Poprad, $4.3 \mathrm{~km}$ na JZ od centra obce Spišská Teplica a $0.5 \mathrm{~km}$ na SSV od kóty Krížový vrch (1102 m n. m.). Najvýraznejšie anomálie sa nachádzajú v záverečnej časti údolia, ktoré je miestnymi obyvatel'mi označované ako "Mokré dolky“. Geografické koordináty centrálnej časti lokality sú N $49^{\circ} 1^{\prime \prime} 17^{\prime \prime}$ a E $20^{\circ} 12^{\prime} 22^{\prime \prime}$.

Rudný výskyt bol preskúmaný len vrtnými prácami a ryhami. Híbkové vrty boli miestami dopĺñané malopri-

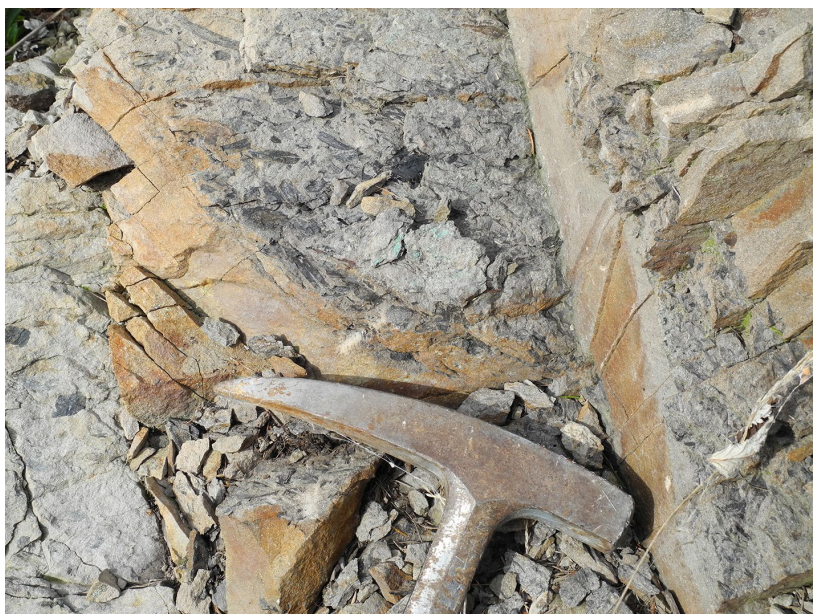

Obr. 2 Odkryv s U-Cu mineralizáciou. Sivé, miestami limonitizované arkózové pieskovce s hojnými fragmentmi zuhol'natenej flóry a zelenými sekundárnymi minerálmi. Foto: Š. Ferenc (2014). emerovými vrtmi orientovanými naprieč rudnou polohou (Tulis, Novotný 1998). Zložitá geologická stavba územia aj tektonické pomery boli príčinou ukončenia prieskumu.

Geologická stavba rudného výskytu Vápenica - Vysová je ilustrovaná na obrázku 1B. Vrchnopermské kravanské vrstvy sú zachované v erozívnych zvyškoch na vrcholoch jednotlivých vyvýšenín. Priebeh kravanského súvrstvia je SSZ - JJV $\left(340^{\circ}\right)$ s úklonom okolo $30^{\circ} \mathrm{k} \mathrm{SSV}$. Tulis a Novotný (I. c.) na základe geologických pomerov predpokladajú výskyt U-Cu zrudnenia $\mathrm{v}$ antiklinálnych úsekoch vrás. Primárna U-Cu mineralizácia je viazaná na polohy tmavosivých/zelenosivých arkózových pieskovcov so zuhol'natenými úlomkami vyšších rastlín (kravanské vrstvy, vrchný perm). Všetky zistené rudonosné šošovky majú malý plošný rozsah aj hrúbku. Rudné polohy lokáIne vychádzajú na povrch, kde vo zvýšenej miere vznikli doposial' bližšie neidentifikované zelené sekundárne minerály.

Mineralizácia na študovanom výskyte je obdobná ako na vyššie uvedených ložiskách U rúd (pozri úvod). Má silnú väzbu na organickú hmotu humínového typu (zvyšky terestriálnych vyšších rastlín). Za zdroj uránu sú považované klasty granitoidov a metamorfovaných hornín veporického kryštalinika. Urán sa nahromadil v organickej hmote, ktorá slúžila ako geochemická bariéra pre cirkulujúce roztoky s obsahom $U$ (redukcia $U^{6+}$ na $U^{4+}$, zníženie mobility a koncentrácia tohto prvku) v pripovrchových podmienkach počas vrchného permu. Ranoalpínske orogénne udalosti zapríčinili čiastočnú remobilizáciu U a tvorbu mladšej uraninitovo-sulfidickej mineralizácie (Rojkovič et al. 1992; Rojkovič 1997).

Uránová mineralizácia $v$ Kozích chrbtoch bola datovaná na ložisku Kravany. U-Pb datovaním uraninitu boli zistené veky 263 - 274 mil. r., zodpovedajúce guadalupskej až lopingskej epoche permu (Legierski in Rojkovič 1997).

\section{Metodika}

Vzorky pre mineralogické štúdium boli odobraté z východov U-Cu zrudnenia na povrch, pomocou rádiometra SGR (rádioaktivita meraná v cps), pri kroku merania 0.2 s a meracom rozsahu 400 - 3000 keV. Zo vzoriek boli následné vyhotovené leštené výbrusy a nábrusy za účelom mikroskopického štúdia v prechádzajúcom aj odrazenom svetle. Niektoré minerálne fázy boli odseparované pod bi-

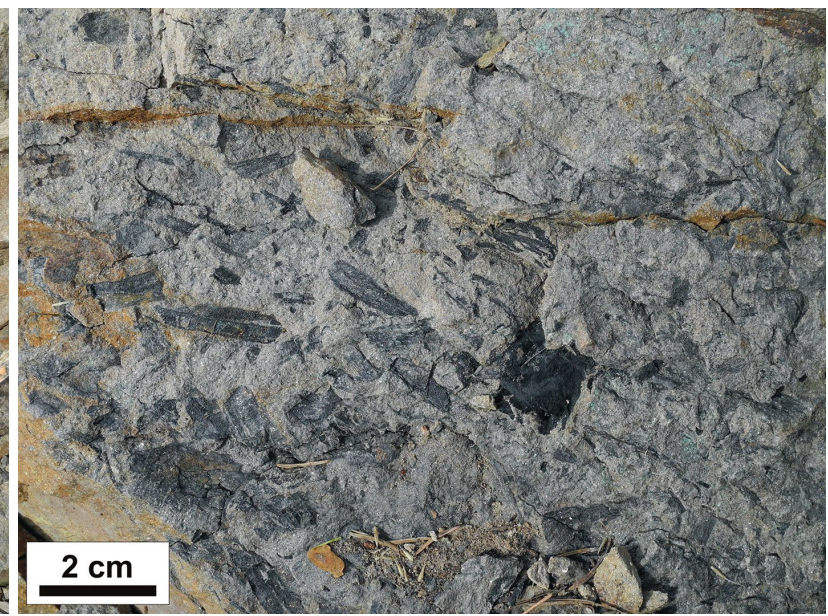

Obr. 3 Detail predchádzajúceho obrázku. Prednostné usporiadanie úlomkov zuhol'natenej flóry je zapríćinený smerom paleoprúdenia v perme. Foto: Š. Ferenc (2014). 
nokulárnou lupou, kvôli infračervenému (IR) spektroskopickému štúdiu.

Chemické zloženie jednotlivých minerálov bolo kvantitatívne študované pomocou elektrónového mikroanalyzátora Jeol - JXA - 8530F (Ústav vied o Zemi SAV, Banská Bystrica). Mikroanalyzátor bol využitý okrem bodových vInovodisperzných mikroanalýz (WDS) aj pre účely fotodokumentácie $v$ spätne rozptýlených elektrónoch (BSE) a neštandardizované, orientačné analýzy (EDS). WDS mikroanalýzy sa robili za nasledujúcich podmienok: urýchlovacie napätie $15 \mathrm{kV}$, merací prúd $15 \mathrm{nA}$ (zálesíit) a 20 nA (monazit, apatit, zirkón). Priemer elektrónového lúča sa pohyboval v rozsahu 1 - $10 \mu \mathrm{m}$, použitá bola korekcia ZAF. Použité prírodné/syntetické štandardy a ich spektrálne čiary boli: $\mathrm{Ca}\left(\mathrm{K}_{\alpha}\right)$ - diopsid, $\mathrm{K}\left(\mathrm{K}_{\alpha}\right)$ - ortoklas, $\mathrm{U}\left(\mathrm{M}_{\beta}\right)-\mathrm{UO}_{2}$, Th $\left(\mathrm{M}_{\alpha}\right)$ - thorianit, $\mathrm{Pb}\left(\mathrm{M}_{\beta}\right)$ - krokoit, $\mathrm{S}\left(\mathrm{K}_{\alpha}\right)$ - barit, $\mathrm{P}\left(\mathrm{K}_{\alpha}\right)$ - apatit, $\mathrm{Y}\left(\mathrm{L}_{\alpha}\right)-\mathrm{YPO}_{4}, \mathrm{Hf}\left(\mathrm{M}_{\alpha}\right)-\mathrm{ZrO}_{2(\mathrm{kub})}, \mathrm{Zr}$ $\left(\mathrm{L}_{\beta}\right)-\mathrm{ZrO}_{2 \text { (kub.) }}, \mathrm{F}\left(\mathrm{K}_{\alpha}\right)$ - fluorit, $\mathrm{Cl}\left(\mathrm{K}_{\alpha}\right)$ - tugtupit, Na $\left(\mathrm{K}_{\alpha}\right)$ - albit, $\operatorname{Sr}\left(\mathrm{L}_{\alpha}\right)$ - celestín, Si $\left(\mathrm{K}_{\alpha}\right)$ - ortoklas, $\mathrm{Al}\left(\mathrm{K}_{\alpha}\right)$ - albit, As $\left(\mathrm{L}_{\alpha}\right)$ - GaAs, $\mathrm{Mg}\left(\mathrm{K}_{\alpha}\right)$ - diopsid, $\mathrm{Lu}\left(\mathrm{L}_{\alpha}\right)-\mathrm{LuPO}_{4}$, Ho $\left(L_{\beta}\right)-\mathrm{HoPO}_{4}, \mathrm{Yb}\left(\mathrm{L}_{\alpha}\right)-\mathrm{YbPO}_{4}, \operatorname{Tm}\left(\mathrm{L}_{\alpha}\right)-\mathrm{TmPO}_{4}, \operatorname{Er}\left(\mathrm{L}_{\alpha}\right)-$ $\mathrm{ErPO}_{4}, \mathrm{Gd}\left(\mathrm{L}_{\beta}\right)-\mathrm{GdPO}_{4}$, Dy $\left(\mathrm{L}_{\alpha}\right)-\mathrm{DyPO}_{4}, \mathrm{~Tb}\left(\mathrm{~L}_{\alpha}\right)-\mathrm{TbPO}_{4}$, $\mathrm{Sm}\left(\mathrm{L}_{\beta}\right)-\mathrm{SmPO}_{4}, \mathrm{Eu}\left(\mathrm{L}_{\alpha},\right)-\mathrm{EuPO}_{4}, \operatorname{Pr}\left(\mathrm{L}_{\beta}\right)-\mathrm{PrPO}_{4}, \mathrm{Nd}$ $\left(\mathrm{L}_{\alpha}\right)-\mathrm{NdPO}_{4}, \mathrm{Ce}\left(\mathrm{L}_{\alpha}\right)-\mathrm{CePO}_{4}$, La $\left(\mathrm{L}_{\alpha}\right)-\mathrm{LaPO}_{4}$, Co $\left(\mathrm{K}_{\alpha}\right)-$ Co, Zn $\left(K_{\alpha}\right)$ - gahnit, Cu $\left(K_{a}\right)$ - kuprit, Fe $\left(K_{\alpha}\right)$ - olivín, Mn $\left(K_{\alpha}\right)$ - rodonit, $\mathrm{Ti}\left(\mathrm{K}_{\alpha}\right)$ - rutil, $\mathrm{Ba}\left(\mathrm{L}_{\alpha}\right)$ - barit, $\mathrm{Bi}\left(\mathrm{M}_{\alpha}\right)-\mathrm{Bi}_{2} \mathrm{Se}_{3}$.
Detekčný limit pre jednotlivé prvky sa pohyboval v rozsahu $0.01-0.08 \mathrm{hm}$. \%. V tabul'kách uvádzaných v d'alšom texte nie sú zahrnuté prvky, ktorých hodnoty obsahu sú pod detekčným limitom.

\section{Výsledky}

\section{Hostitel'ská hornina a primárna mineralizácia}

Mineralizácia v doline Mokré dolky (rudný výskyt Vápenica - Vysová) je viazaná na polohy arkózových pieskovcov (lokálne s vulkanickou prímesou) vrchnopermského veku (obr. 2, 3). Zo štruktúrneho hl'adiska ide o relatívne dobre vytriedený jemnozrnný pieskovec tvorený angulárnymi až subangulárnymi klastmi, ktorých vel'kost' sa $v$ priemere pohybuje okolo $0.1-0.2 \mathrm{~mm}$, zriedkavo sú klasty vel'ké do $0.8 \mathrm{~mm}$. Z klastickej zložky horniny jednoznačne dominuje kremeň (undulozita nebola pozorovaná). Klasty kremeňa sú väčšinou polykryštalické, menej často sú monokryštalické. $V$ menšej miere je hornina tvorená plagioklasmi (ktoré absolútne prevažujú nad draselným živcom) a muskovitom. Zrná plagioklasov vykazujú výrazné polysyntetické lamely. Podlhovasté agregáty kryštálov muskovitu sú pomerne často deformované transportom. $V$ akcesorickom množstve je prítomný zirkón, fluórapatit, monazit-(Ce) a leukoxenizované Fe-Ti oxidy. Okrem toho hornina ešte obsahuje preplástky seri-
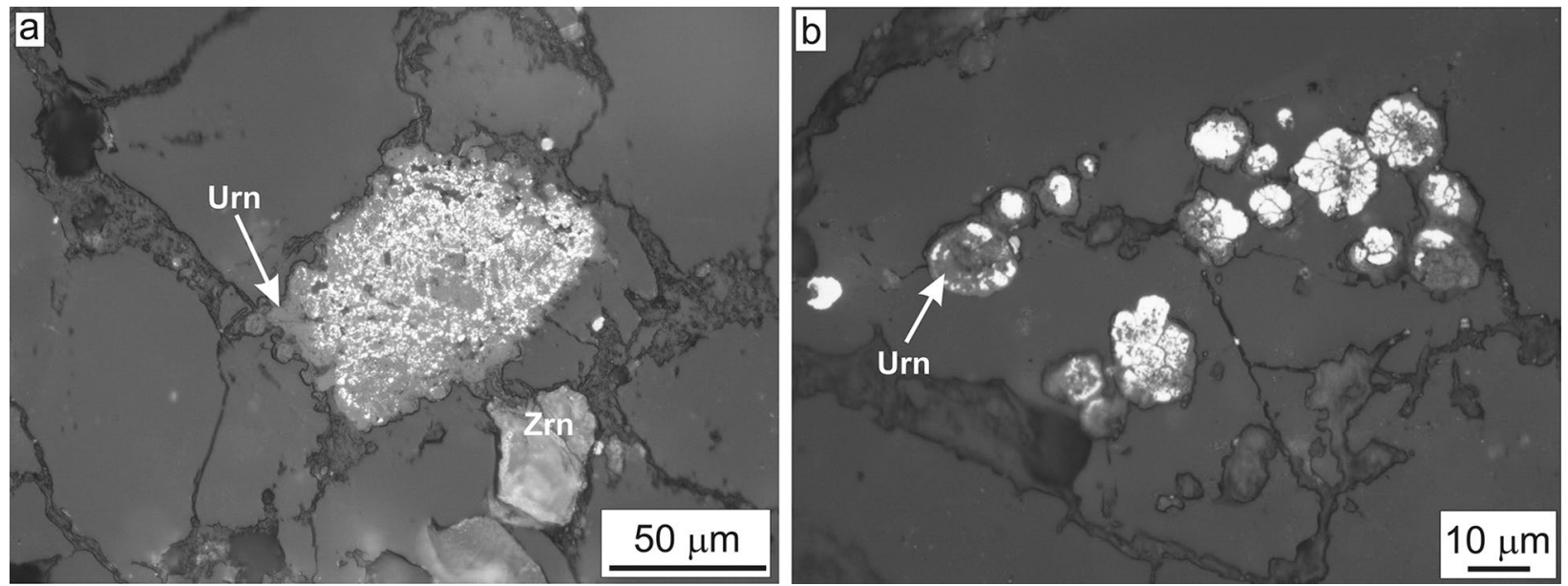

Obr. 4a) Uraninit (Urn) prerastá s pyritom (biely). Okolie uraninitovo-pyritového agregátu je tvorené klastickým kremeňom (sivý) a akcesorickým zirkónom (Zrn). b) Framboidálny pyrit (biely) je zatláčaný uraninitom (sivý). Okolie je tvorené kremeňom (+ matrix horniny). Odrazené svetlo. Foto: Š. Ferenc.
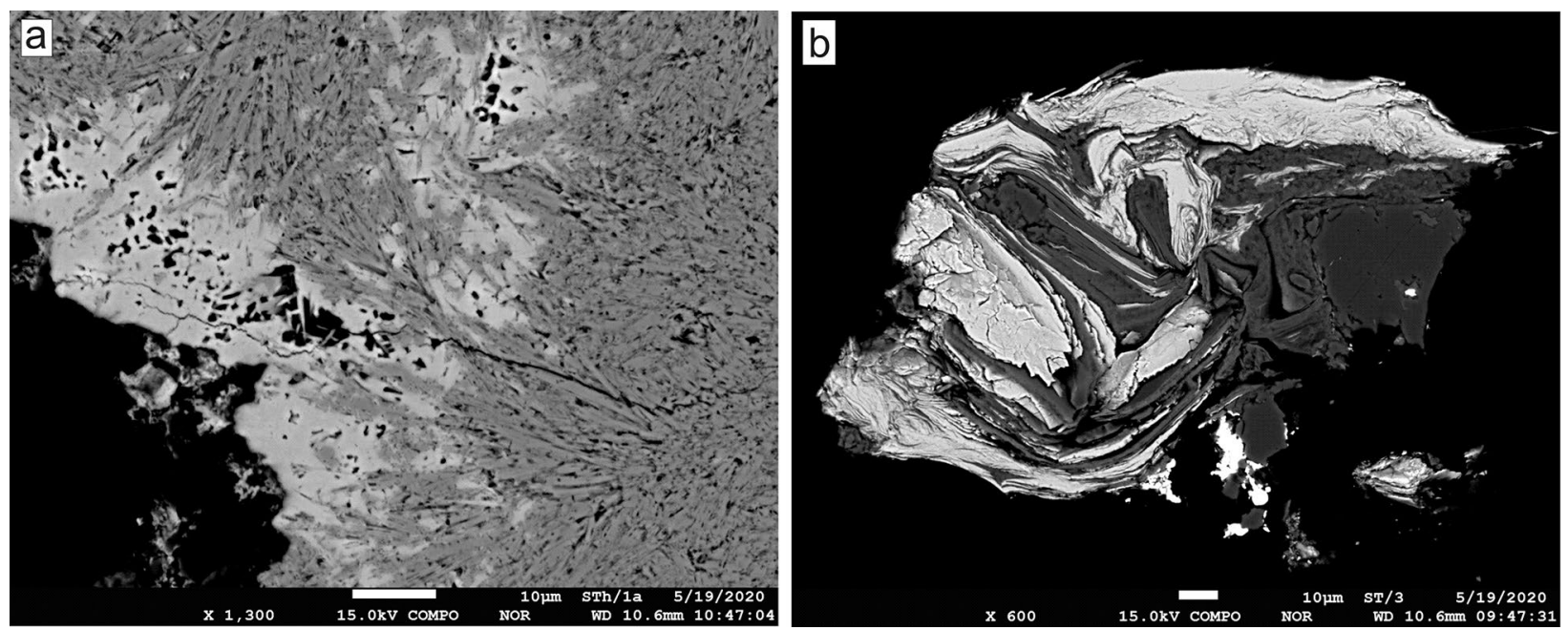

Obr. 5a) Agregát ihlicovitých kryštálov malachitu (tmavosivý) je zatláčaný zálesiitom (svetlosivý). b) Malachit (sivobiely) prerastá s klastickým muskovitom (sivočierny). BSE obrázky. Foto: T. Mikuš. 
citizovaných, sklovitých vulkanoklastík. V zrudnenom pieskovci možno často pozorovat zuhol'natené zvyšky rastlín. Tmel horniny je karbonátový, miestami karbonátovo-sericitický.

Rudná, infiltračná mineralizácia je reprezentovaná uraninitom a pyritom. Uraninit tvorí nepravidelné svetlosivé zrná aj sféroidy s vel'kost'ou do $0.1 \mathrm{~mm}$ (obr. 4a) a prakticky vždy prerastá s pyritom. Pyrit tiež tvorí samostatné framboidálne agregáty vel'ké do $0.02 \mathrm{~mm}$, ktoré sú zatláčané a obrastané uraninitom (obr. 4b). Dutiny a drobné pukliny $v$ hornine sú vyplnené supergénnym goethitom a malachitom. Hrúbka puklín je variabilná, nepresahuje však $0.1 \mathrm{~mm}$.

$\mathrm{V}$ akcesorických mineráloch boli zriedkavo zistené inklúzie sulfidov Cu (vel'kost' do $10 \mu \mathrm{m})$, ktoré však nesúvisia s infiltračnou U-Cu mineralizáciou, ale reprezentujú produkt kryštalizácie horninotvorných minerálov veporických granitoidov, zdrojových hornín pre arkózy kravanského súvrstvia. Inklúzie chalkopyritu boli nájdené $v$ zrnách klastického fluórapatitu. V zirkóne boli pozorované inklúzie Cu-S minerálu (neštandardizovaná EDS analýza: 78 hm. \% Cu, 22 hm. $\%$ S), ktorý svojim zložením zodpovedá digenitu - roxbyitu.

\section{Supergénne minerály}

Malachit je na študovanej lokalite najhojnejším minerálom. Bol identifikovaný IR spektroskopiou a neštandardizovanou EDS analýzou. Tvorí mentolovo, respektíve svetlozelené kôry so zemitým leskom na povrchu hornín (hrúbka do $1 \mathrm{~mm}$ ), na ploche maximálne $1-2 \mathrm{~cm}^{2}$, alebo výplne puklín v hornine. Pomerne často sa prerastá s goethitom, zriedkavejšie so zálesíitom. Malachitové kôry majú (v mikromierke) prevažne masívny charakter, lokálne sú však zložené z agregátov ihlicovitých kryštálov s dížkou do $50 \mu \mathrm{m}$ (obr. $5 a)$. $V$ niektorých prípadoch malachit vniká do priestorov medzi tabul'kovitými kryštál-

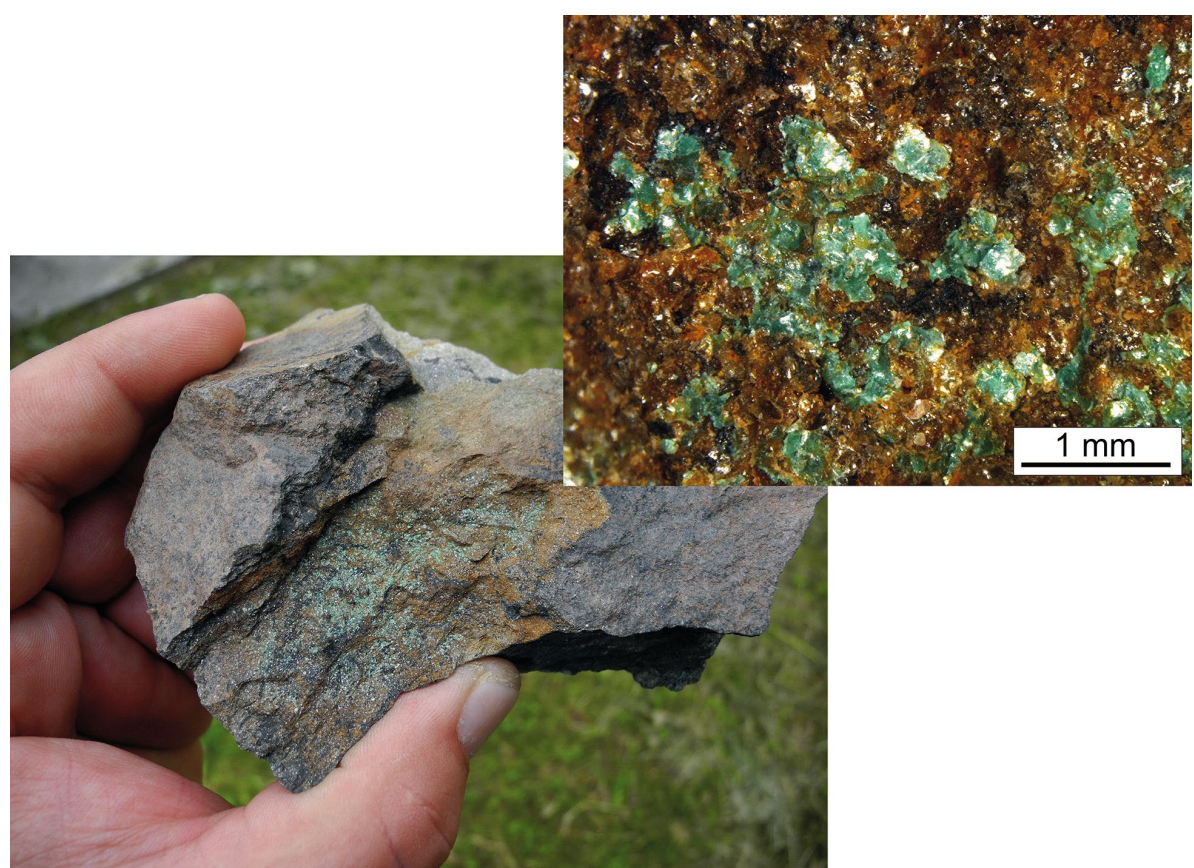

Obr 6. Mineralizovaný pieskovec z výskytu Vápenica - Vysová (aktivita 590 - 610 cps) potiahnutý zelenými šupinkami „falošnej uránovej sludy“ (obrázok vlavo dole). Vpravo hore je detailný pohlad na muskovitovo-malachitové agregáty na povrchu pieskovca. Foto: Š. Ferenc.

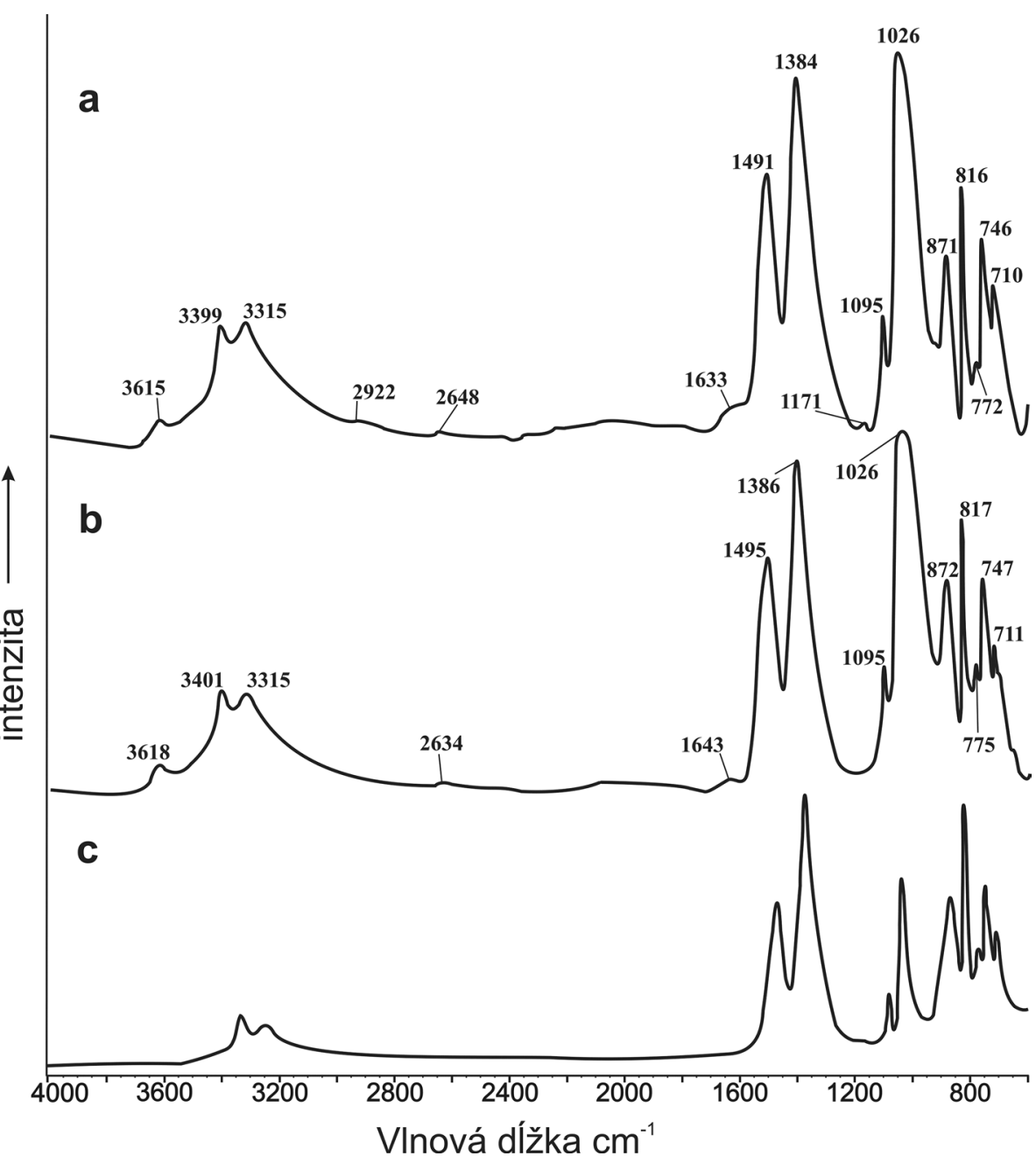

Obr. 7a, b) Infračervené spektrá malachitu z výskytu Vápenica - Vysová. c) Spektrum malachitu publikované v databáze RRUFF (Lafuente et al. 2015). Rozsah vinovej dĺžky 4000 - $600 \mathrm{~cm}^{-1}$. 
mi v agregátoch klastického muskovitu (obr. 5b). Takáto priestorová asociácia spôsobuje, že na povrchu navetraných vzoriek U rudy sú už vol'ným okom pozorovatel'né lesklé, zelené šupinky (obr. 6), ktoré vel'mi presvedčivo pôsobia dojmom zelených Cu-U minerálov autunitovej skupiny (napr. torbernit, zeunerit). Okrem opisovanej lokality sú takéto zelené muskovity charakteristické zvlášt' pre ložisko Vikartovce. Je možné, že tomuto klamlivému dojmu mohli v minulosti podlahnút' aj pracovníci uránového priemyslu („terénna mineralógia“), pri prieskume ložísk v Dúbrave. Nasvedčujú tomu časté zmienky o „uránových sludách" v nepublikovaných správach, pričom je potrebné podotknút', že supergénne uránové minerály sa, na základe našich skúseností, práve $v$ oblasti Dúbravy $v$ tejto forme takmer nevyskytujú. Väčšinou tvoria jemnozrnné povlaky a kôry zelenej a žltej farby.

Infračervené spektrá malachitu zo Spišskej Teplice (obr. 7) sú takmer súhlasné s publikovanými spektrami pre túto minerálnu fázu $v$ internetových databázach RRUFF (Lafuente et al. 2015), SpectraBase a v prácach Schmidt, Lutz (1993); Stoilova et al. (2002); Miliani et al. (2012); Buti et al. (2013). Pásy v spektrálnej oblasti približne $1510-1350 \mathrm{~cm}^{-1}$ možno priradit' $\mathrm{k}$ valenčným vibráciám $\mathrm{v}_{3}$ antisymetrického napínania $\mathrm{CO}_{3}{ }^{2-}$. Pomerne výrazné a ostré pásy pri $816 \mathrm{~cm}^{-1}$ (obr. $7 \mathrm{a}$ ), $817 \mathrm{~cm}^{-1}$ (obr. $7 \mathrm{~b})$ a k nim patriace ramená pri $871 \mathrm{~cm}^{-1}(7 \mathrm{a}), 872 \mathrm{~cm}^{-1}$ (7b) patria podl'a práce Stoilova et al. (2002) valenčným vibráciám $\mathrm{v}_{2}$ (mimo roviny $\mathrm{CO}_{3}{ }^{2-}$ väzby), menej výrazné skupiny vibračných pásov pri $772,746,710 \mathrm{~cm}^{-1}$ (7a) a $775,747,711 \mathrm{~cm}^{-1}(7 \mathrm{~b})$ patria $\mathrm{k}$ valenčným vibráciám $\mathrm{v}_{4}$ $\checkmark$ rovine $\mathrm{CO}_{3}{ }^{2-}$ väzby. Pásy $v$ spektrálnej oblasti s hodno-

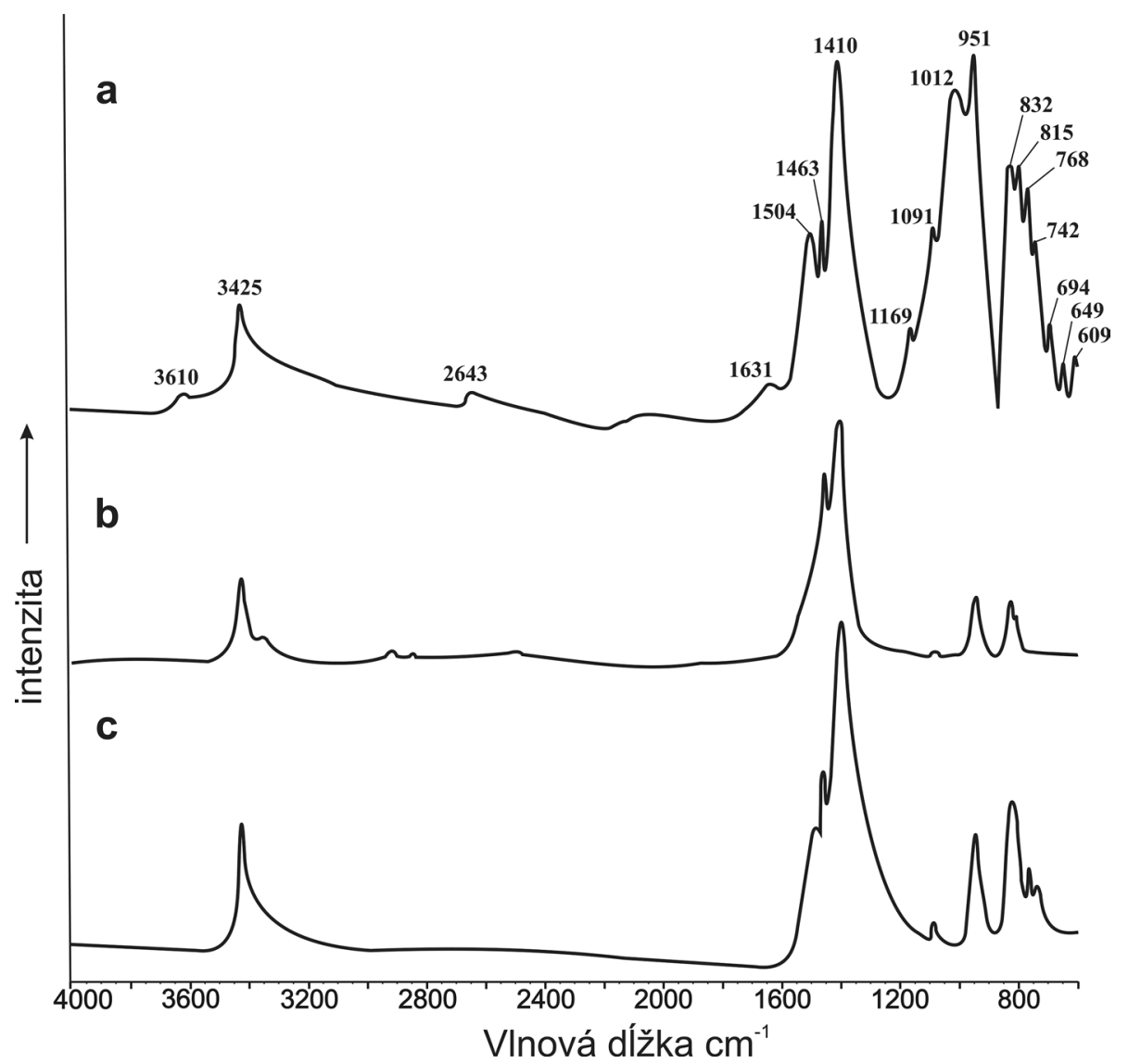

Obr. 8a) Infračervené spektrum azuritu z výskytu Vápenica - Vysová. b) Spektrum azuritu publikované v práci Salvadó et al. (2014). c) Spektrum azuritu publikované $v$ databáze RRUFF (Lafuente et al. 2015). Rozsah vlnovej dížky $4000-600 \mathrm{~cm}^{-1}$. tami nižšími ako $600 \mathrm{~cm}^{-1}$ sú prirad’ované väzbám Cu-O - silné Cu-O interakcie (Schmidt, Lutz 1993). V zmysle prác Schmidt, Lutz (1993); Stoilova et al. (2002) a Miliani et al. (2012) sú valenčné vibrácie $v_{1}$ (symetrické napínanie $\mathrm{CO}_{3}^{2-}$ ) reprezentované najvýraznejším pásom na pozícii $1085 \mathrm{~cm}^{-1}$. Tomu môžu zodpovedat' pásy spektier malachitu zo Spišskej Teplice pri vlnových dížkach 1026 $\mathrm{cm}^{-1} \mathrm{~s}$ ramenom pri $1095 \mathrm{~cm}^{-1}(7 \mathrm{a}, \mathrm{b})$. Uvedené pásy sa však prekrývajú s libračným módom $\delta$ O-H (Stoilova et al. 2002; Buti et al. 2013). Spektrálne pásy pri 3399 a 3315 $\mathrm{cm}^{-1}$ (7a), 3401 a $3315 \mathrm{~cm}^{-1}(7 \mathrm{~b})$ prislúchajú napínaniu $\mathrm{O}-\mathrm{H}$ väzieb (valenčné vibrácie $\mathrm{v}_{3}+\mathrm{v}_{1}$; Buti et al. 2013) $v$ dvoch kryštalograficky odlišných O-H iónov v mriežke malachitu (Schmidt, Lutz 1993). Pásy na pozíciách 2922 a $2648 \mathrm{~cm}^{-1}(7 \mathrm{a}), 2634 \mathrm{~cm}^{-1}$ (7b) sú priradené tiež k módu $\mathrm{O}-\mathrm{H}$ (valenčné vibrácie $\mathrm{v}_{1}$; Stoilova et al. 2002). Nevýrazné pásy pri $3615(7 \mathrm{a})$ a $3618 \mathrm{~cm}^{-1}(7 \mathrm{~b})$ sú pravdepodobne prejavom kombinácie napínania $\mathrm{O}-\mathrm{H}$ väzieb (valenčné vibrácie $v_{3}+v_{1}$ ) a deformačného napínania $\mathrm{Cu}-\mathrm{OH}$ módov (synenergetický účinok). Napínanie v danej spektráInej oblasti môže naznačovat' silnú, čiastočne kovalentnú Cu-O väzbu (Stoilova et al. 2001; Miliani et al. 2012; Buti et al. 2013). DÍžka vodíkovej väzby v malachite bola vypočítaná na základe vzt’ahu publikovaného v práci Libowitzskeho (1999) a pohybovala sa v rozsahu $2.58-2.81 \AA$.

Azurit (IR spektroskopia, neštandardizovaná EDS analýza) je oproti malachitu len podradne zastúpený. Tvorí drobné, typicky sýtomodré náteky a kryštalické kôry vel'kost'ou do $2 \mathrm{~mm}$. Infračervené spektrum azuritu zo Spišskej Teplice (obr. 8a) je takmer identické s publikovanými spektrami pre túto minerálnu fázu, napr. databáza RRUFF (Lafuente et al. 2015), tiež práce Farmer (1974); Schmidt, Lutz (1993); Miliani et al. (2012) a Salvadó et al. (2014). Prítomnost' vody $\mathrm{v}$ karbonátoch charakterizujú pásy $v$ spektrálnej oblasti $3600-3300 \mathrm{~cm}^{-1}$, čo je oblast' základného napínania O-H väzby (Farmer 1974). $\checkmark$ prípade azuritu ide približne o hodnotu pásu pri $3425 \mathrm{~cm}^{-1}$ (Farmer 1974; Miliani et al. 2012), ktorý Schmidt a Lutz (1993) dávajú do súvisu s valenčnými vibráciami $v_{1}$ (napínanie $\mathrm{O}-\mathrm{H}$ väzieb). Uvedená hodnota je zhodná $s$ pásom $\checkmark$ analyzovanej vzorke zo Spišskej Teplice (obr. 8a). Na základe Fresnelovho zákona možno silné pásy $v$ oblasti $1500-1400 \mathrm{~cm}^{-1}$ priradit' $\mathrm{k}$ antisymetrickému napínaniu $\mathrm{v}_{3}$ $\mathrm{CO}_{3}{ }^{2-}$, zatial' čo pásy $v$ spektrálnej oblasti okolo $1000 \mathrm{~cm}^{-1}$ súvisia s valenčnými vibráciami $\mathrm{v}_{1}$, resp. symetrickým napínaním $\mathrm{CO}_{3}{ }^{2-}$ (Farmer 1974; Miliani et al. 2012). Kombinácia valenčných vibrácii $v_{1}+v_{4}$ $\left(\mathrm{CO}_{3}{ }^{2-}\right)$ nižších vinových dížok (t.j. v širšej oblasti okolo 1800 $\mathrm{cm}^{-1}$ ) je v zmysle prác Miliani et al. (2012) a Buti et al. 
(2013) priradená k pásu $1631 \mathrm{~cm}^{-1}$. Pásy v pozícii 3610, 3425 a $2643 \mathrm{~cm}^{-1}$ súvisia s napínaním O-H väzieb, rovnako ako $v$ prípade malachitu. $Z$ výsledkov práce Schmidta a Lutza (1993) vyplýva zaradenie jednotlivých pásov: $3610 \mathrm{~cm}^{-1}$ a $3425 \mathrm{~cm}^{-1} \mathrm{k}$ napínaniu $\mathrm{O}-\mathrm{H}$ väzby valenčnej vibrácie $v_{1}$. Pás pri $2643 \mathrm{~cm}^{-1}$ je pravdepodobne dôsledkom kombinácie valenčných vibrácií $\mathrm{v}_{1}+\mathrm{v}_{3}\left(\mathrm{CO}_{3}{ }^{2-}\right)$, čo sú typické kombinácie karbonátov medi (Ricci et al. 2006;
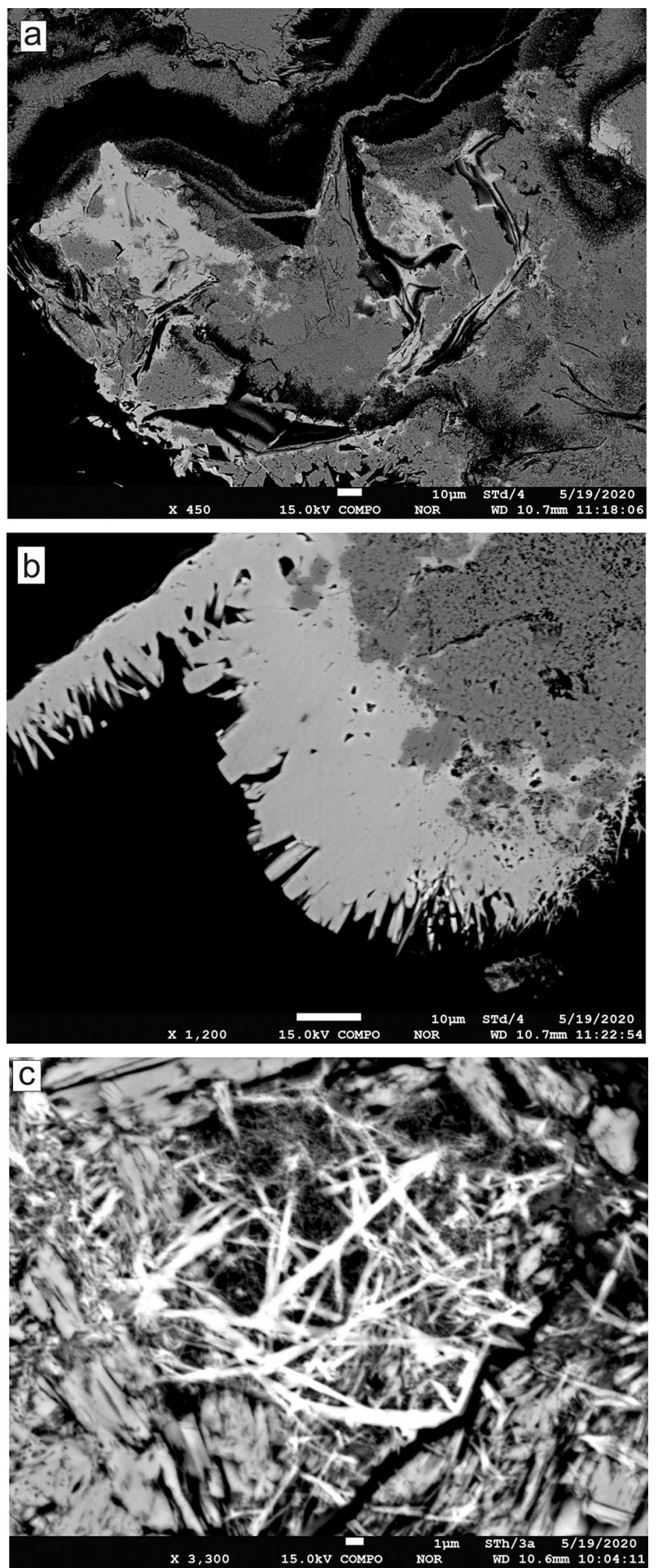

Obr. 9a) Zálesiit (svetlosivý) prerastajúci s pomerne kompaktným (ale pórovitým) malachitom (tmavosivý). b) Ihlicovité kryštály zálesíitu (svetlosivé) narastajúce na malachit (tmavosivý). c) "Mikrovlákna“ zálesiitu (biele) v dutine malachitového agregátu (svetlosivý). BSE obrázky. Foto: T. Mikuš.
Miliani et al. 2012). Buti et al. (2013), však tento pás prirad'ujú $\mathrm{k}$ valenčným vibráciám $2 \mathrm{v}_{2}+\mathrm{v}_{4}\left(\mathrm{CO}_{3}{ }^{2-}\right)$, alebo $\mathrm{k}$ módu O-D väzieb, resp. valenčným vibráciám $v_{1}$ (sensu Schmidt, Lutz 1993). DÍžka vodíkovej väzby v azurite bola vypočítaná na základe vzt’ahu publikovaného $v$ práci Libowitzskeho (1999). Pohybovala sa v rozsahu 2.58 - 2.82 Å. V porovnaní s výsledkami prác Emsley (1980), Libowitzky (1999), Gao, Yuan (2020) možno konštatovat',

Tabul'ka 1 Chemické zloženie zálesiitu zo Spišskej Teplice (rudný výskyt Vápenica - Vysová)

\begin{tabular}{lrrrrrrr}
\hline & 1 & 2 & 3 & 4 & 5 & 6 & mean \\
\hline $\mathrm{K}_{2} \mathrm{O}$ & 0.15 & 0.15 & 0.10 & 0.03 & 0.01 & 0.02 & 0.08 \\
$\mathrm{CaO}$ & 1.95 & 2.15 & 2.69 & 1.73 & 2.48 & 2.32 & 2.22 \\
$\mathrm{BaO}$ & 0.08 & 0.24 & 0.18 & 0.09 & 0.03 & 0.00 & 0.10 \\
$\mathrm{FeO}$ & 0.19 & 0.29 & 0.31 & 1.82 & 0.23 & 0.23 & 0.51 \\
$\mathrm{PbO}$ & 0.23 & 0.17 & 0.20 & 0.56 & 0.18 & 0.21 & 0.26 \\
$\mathrm{Al}_{2} \mathrm{O}_{3}$ & 1.35 & 1.26 & 0.63 & 2.37 & 0.11 & 0.05 & 0.96 \\
$\mathrm{Y}_{2} \mathrm{O}_{3}$ & 5.90 & 5.44 & 5.43 & 2.91 & 4.57 & 4.19 & 4.74 \\
$\mathrm{La}_{2} \mathrm{O}_{3}$ & 0.02 & 0.02 & 0.00 & 0.31 & 0.24 & 0.23 & 0.14 \\
$\mathrm{Ce}_{2} \mathrm{O}_{3}$ & 0.06 & 0.07 & 0.03 & 1.24 & 0.55 & 0.59 & 0.42 \\
$\mathrm{Nd}_{2} \mathrm{O}_{3}$ & 0.00 & 0.07 & 0.01 & 1.10 & 0.60 & 0.69 & 0.41 \\
$\mathrm{Dy}_{2} \mathrm{O}_{3}$ & 0.28 & 0.22 & 0.22 & 0.07 & 0.16 & 0.26 & 0.20 \\
$\mathrm{UO}_{2}$ & 0.36 & 0.33 & 0.25 & 0.78 & 1.29 & 0.58 & 0.60 \\
$\mathrm{CuO} \mathrm{O}$ & 43.77 & 45.69 & 46.59 & 42.42 & 47.09 & 44.74 & 45.05 \\
$\mathrm{SiO}_{2}$ & 2.20 & 1.69 & 1.31 & 0.59 & 0.79 & 0.70 & 1.21 \\
$\mathrm{P}_{2} \mathrm{O}_{5}$ & 0.84 & 0.68 & 0.69 & 0.76 & 0.20 & 0.22 & 0.56 \\
$\mathrm{As}_{2} \mathrm{O}_{5}$ & 29.95 & 28.12 & 30.19 & 30.80 & 33.13 & 32.10 & 30.71 \\
$\mathrm{SO}_{3}$ & 0.36 & 0.35 & 0.61 & 0.59 & 0.03 & 0.01 & 0.33 \\
$\mathrm{H}_{2} \mathrm{O}^{*}$ & 8.24 & 8.23 & 8.21 & 8.08 & 7.99 & 8.03 & 8.13 \\
\hline$\Sigma \mathrm{Im}_{4} \%$ & 95.92 & 95.17 & 97.65 & 96.25 & 99.67 & 95.15 & 96.64
\end{tabular}

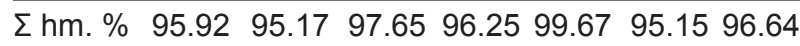
kryštalochemické koeficienty

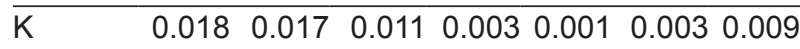
$\begin{array}{lllllllll}\mathrm{Ca} & & 0.385 & 0.407 & 0.499 & 0.337 & 0.461 & 0.456 & 0.424\end{array}$

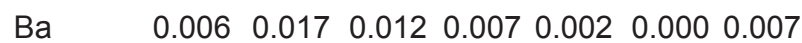

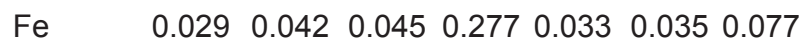

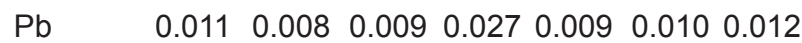

$\begin{array}{lllllllll}\text { Al } & & 0.146 & 0.132 & 0.064 & 0.255 & 0.011 & 0.005 & 0.102\end{array}$

$\begin{array}{llllllllll}Y & & 0.289 & 0.255 & 0.250 & 0.141 & 0.211 & 0.205 & 0.225\end{array}$

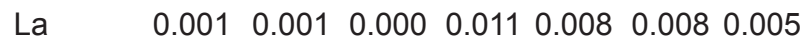

$\begin{array}{lllllllll}\mathrm{Ce} & & 0.002 & 0.002 & 0.001 & 0.042 & 0.017 & 0.020 & 0.014\end{array}$

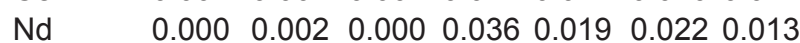

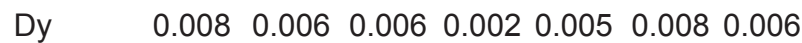

$\begin{array}{lllllllll}\text { U } & & 0.015 & 0.013 & 0.010 & 0.032 & 0.050 & 0.024 & 0.024\end{array}$

\begin{tabular}{lllllllll}
\hline$\Sigma A$ & & 0.910 & 0.903 & 0.908 & 1.169 & 0.825 & 0.795 & 0.919
\end{tabular} \begin{tabular}{llllllll}
\hline$\Sigma Y+R E E$ & 0.300 & 0.267 & 0.258 & 0.231 & 0.259 & 0.263 & 0.263
\end{tabular} \begin{tabular}{lllllllll}
\hline $\mathrm{Cu}$ & & 6.090 & 6.097 & 6.092 & 5.831 & 6.175 & 6.205 & 6.081
\end{tabular}

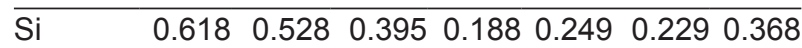
$\begin{array}{lllllllll}P & & 0.100 & 0.090 & 0.087 & 0.103 & 0.026 & 0.030 & 0.073\end{array}$ As $\quad \begin{array}{llllllll}2.205 & 2.300 & 2.380 & 2.569 & 2.718 & 2.738 & 2.485\end{array}$ $\begin{array}{lllllllll}S & & 0.077 & 0.082 & 0.138 & 0.141 & 0.007 & 0.002 & 0.075\end{array}$ \begin{tabular}{llllllll}
\hline$\Sigma T$ & 3.000 & 3.000 & 3.000 & 3.000 & 3.000 & 3.000 & 3.000
\end{tabular}

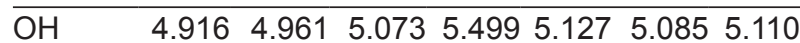
$\begin{array}{llllllll}\mathrm{H}_{2} \mathrm{O} & 3.000 & 3.000 & 3.000 & 3.000 & 3.000 & 3.000 & 3.000\end{array}$ \begin{tabular}{llllllll}
\hline $\mathrm{Ca} / \Sigma A$ & 0.42 & 0.45 & 0.55 & 0.29 & 0.56 & 0.57 & 0.46
\end{tabular} $\begin{array}{lllllllll}Y / \Sigma A & 0.32 & 0.28 & 0.28 & 0.12 & 0.26 & 0.26 & 0.25\end{array}$ $\begin{array}{llllllll}\mathrm{Al} / \Sigma A & 0.16 & 0.15 & 0.07 & 0.22 & 0.01 & 0.01 & 0.11\end{array}$ $\begin{array}{llllllll}\mathrm{Pb} / \Sigma A & 0.01 & 0.01 & 0.01 & 0.02 & 0.01 & 0.01 & 0.01\end{array}$ Empirický vzorec zálesíitu bol prepočítaný na 10 atómov. $\mathrm{H}_{2} \mathrm{O}^{*}$ - obsah vody bol dopočítaný na základe ideálneho vzorca minerálu a vyrovnania nábojov. 
že vodíková väzba je v azurite a rovnako aj v malachite slabá.

Zálesíit (WDS analýzy) je na lokalite pomerne častý, ale iba v podradnom množstve a v mikroskopickej vel'kosti. Vystupuje vždy v tesnej asociácii s malachitom. Tvorí dve morfologické formy. Najrozšírenejší je kompaktný zálesíit obrastajúci inlicovité agregáty malachitu (obr. 5a), alebo tvoriaci hniezda (vel'kost' do $100 \mu \mathrm{m}$ ) a žilky v masívnych malachitových kôrach (obr. 9a). Tiež tvorí agregáty krátkych (do $30 \mu \mathrm{m})$ ihlicovitých kryštálov narastajúce na malachit (obr. 9b), resp. až vláknité kryštály v dutinách malachitu (obr. 9c).

Chemické zloženie zálesíitu zo Spišskej Teplice je uvedené v tabul'ke 1. Podl'a všeobecného chemického vzorca minerálov mixitovej skupiny $A \mathrm{Cu}_{6}\left(\mathrm{TO}_{4}\right)_{3}(\mathrm{OH})_{6} \cdot 3 \mathrm{H}_{2} \mathrm{O}(\mathrm{Olmi}$ et al. 1991), prevažuje $v$ študovanom mineráli na pozícii $A$ jednoznačne zálesíitová molekula (1.95 - $2.69 \mathrm{hm}$. \% $\mathrm{CaO} ; 0.39$ - 0.5 apfu Ca) nad ytrioagarditovou (2.90 - 5.90 $\mathrm{hm}$. \% $\mathrm{Y}_{2} \mathrm{O}_{3} ; 0.14-0.29$ apfu Y). Obsah REE je variabilný (0.26 - 2.73 hm. \% REE $\mathrm{O}_{3} ; 0.01$ - 0.09 apfu REE), z nich dominantnejšie (avšak pomerne nerovnomerne distribu- ované) sú LREE (priemerne $0.97 \mathrm{hm} . \% \operatorname{LREE}_{2} \mathrm{O}_{3} ; 0.03$ apfu LREE). Ťažké REE sú zastúpené jedine stabilnejšie prítomným Dy (priemerne $0.20 \mathrm{hm}$. $\% \mathrm{Dy}_{2} \mathrm{O}_{3} ; 0.01$ apfu Dy). V študovanej minerálnej fáze sa najvýraznejšie uplatňuje heterovalentná substitúcia $\mathrm{Ca} \leftrightarrow \mathrm{Al}$, pri relatívne konštantnom obsahu Y, resp. Y+REE (obr. 10a, b). Obsah goudeyitovej zložky kolíše v rozmedzí $0.11-2.37$ hm. \% $\mathrm{Al}_{2} \mathrm{O}_{3}(0.01-0.26$ apfu $\mathrm{Al})$. Ostatné prvky sú zastúpené nepodstatne (tab. 1). Pozícia $T$ je dominantne obsadená As (priemerne $30.71 \mathrm{hm}$. \% $\mathrm{As}_{2} \mathrm{O}_{5} ; 2.48$ apfu As), fosfor je stabilne zastúpený (priemerne $0.56 \mathrm{hm} . \% \mathrm{P}_{2} \mathrm{O}_{5} ; 0.07$ apfu P), výraznejšie zvýšený je obsah Si (0.59 - $2.20 \mathrm{hm}$. $\% \mathrm{SiO}_{2} ; 0.19$ - 0.62 apfu Si). Obsah S nemá väčší význam. Priemerný empirický vzorec zálesíitu zo Spišskej Teplice možno vyjadrit' ako $\left(\mathrm{Ca}_{0.42} \mathrm{Y}_{0.23} \mathrm{REE}_{0.03} \mathrm{Al}_{0.10} \mathrm{Fe}_{0.08} \mathrm{U}_{0.02}\right.$ $\left.\mathrm{Ba}_{0.01} \mathrm{~Pb}_{0.01} \mathrm{~K}_{0.01}\right)_{\Sigma 0.91} \mathrm{Cu}_{6.08}\left[\left(\mathrm{AsO}_{4}\right)_{2.48}\left(\mathrm{SiO}_{4}\right)_{0.37}\left(\mathrm{PO}_{4}\right)_{0.07}^{0.02}\right.$ $\left.\left(\mathrm{SO}_{4}\right)_{0.07}\right]_{\Sigma 2.99}(\mathrm{OH})_{5.11} \cdot 3 \mathrm{H}_{2} \mathrm{O}$.

Barit tvorí výplne vlásočnicových puklín a drobných dutín v hornine, kde sa nachádza $v$ asociácii $s$ malachitom a bližšie neurčenou zmesou supergénnych minerálov $\mathrm{Fe}-\mathrm{As}-\mathrm{Cu}$.

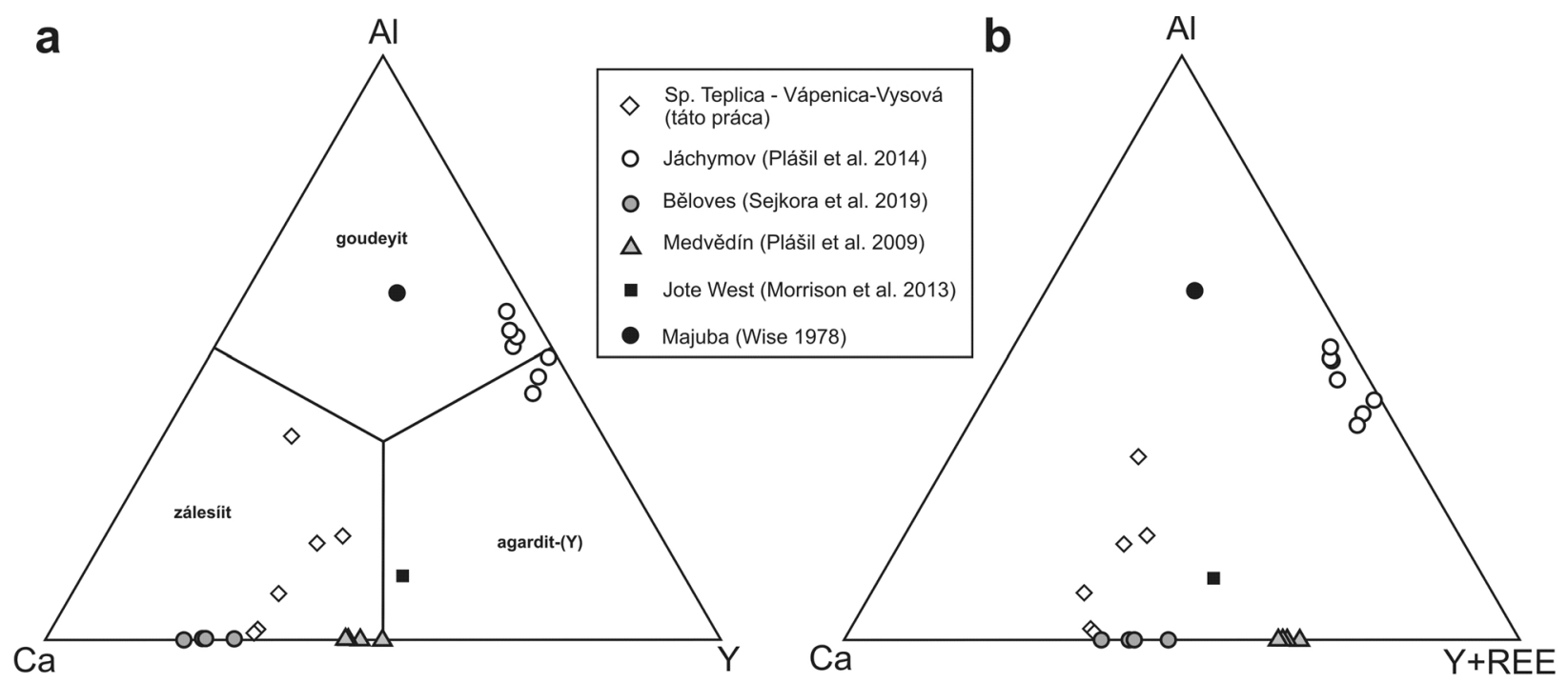

Obr. 10a) Priemety mikroanalýz zálesíitu zo Spišskej Teplice v porovnaní s niektorými publikovanými analýzami minerálov mixitovej skupiny v systéme Ca-Al-Y a Ca-Al-Y+REE (obrázok b).

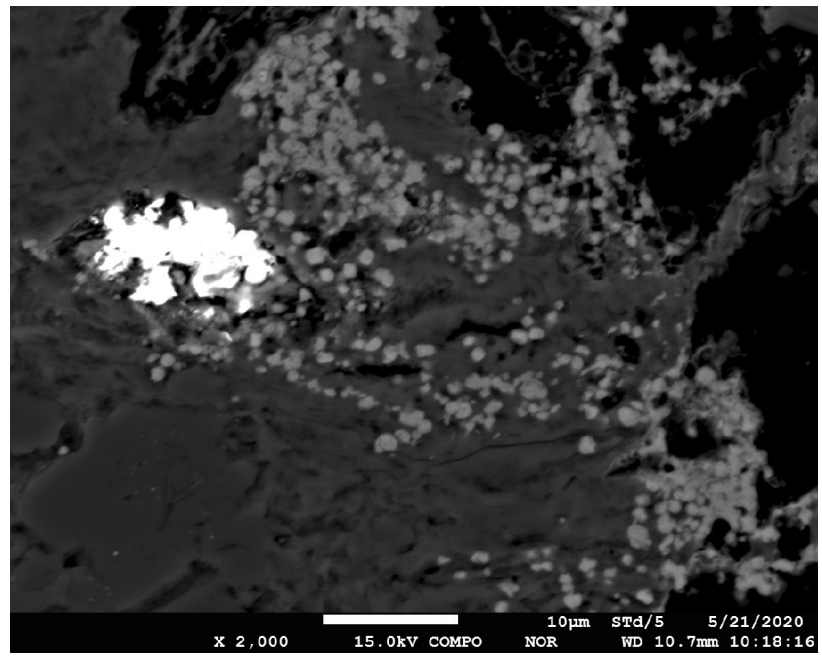

Obr. 11 Kríčkovitý agregát akantitu (biely) v dutine kremeňa (tmavosivý) sprevádzaný globulárnymi agregátmi minerálu florencitovej (?) skupiny. BSE obrázok. Foto: T. Mikuš.

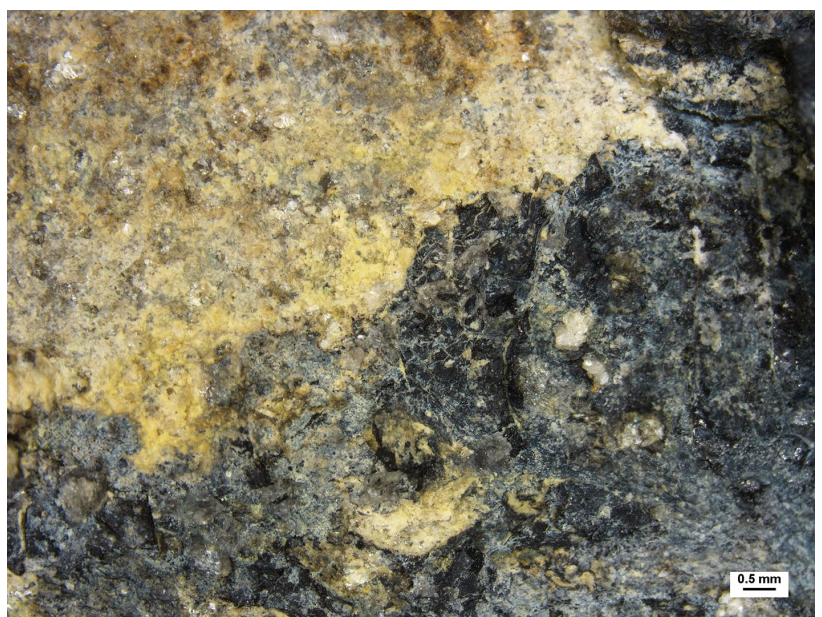

Obr. 12 Zvetraná uránová ruda z ložiska Kravany (aktivita cca 2500 cps); povrch pieskovca v kontakte $s$ fragmentom zuhol'natenej flóry. Supergénny uranofán (svetložltý) je bohatšie zastúpený v hostitel'skom pieskovci, zatial' čo na povrchu uhlia je zastúpený iba v malej miere. Foto: Š. Ferenc. 
Akantit bol zistený iba ojedinele. Tvoril kríčkovitý agregát vel'ký okolo $12 \mu \mathrm{m} v$ dutine pieskovca (obr. 11), v asociácii s bližšie neurčeným fosfátom florencitovej (?) skupiny (neštandardizovaná EDS analýza: $0.7 \mathrm{~K}_{2} \mathrm{O}, 2.7$ $\mathrm{MgO}, 1.9 \mathrm{CaO}, 45.7 \mathrm{Al}_{2} \mathrm{O}_{3}, 3.9 \mathrm{La}_{2} \mathrm{O}_{3}, 10.4 \mathrm{CeO}_{2}, 31.7$ $\mathrm{P}_{2} \mathrm{O}_{5}, 3.1 \mathrm{SO}_{3} \mathrm{hm}$. \%). Jeho malé rozmery neumožnili použit' WDS analýzu so širokým lúčom, obvyklú pri Ag mineráloch (únik Ag pri analyzovaní). Neštandardizovaná EDS analýza preukázala $v$ agregáte iba obsah $\mathrm{Ag}$ a $\mathrm{S}$, ktorý sa prakticky zhodoval s ideálnym zložením tohto minerálu ( $87 \mathrm{hm} . \% \mathrm{Ag}, \sim 13 \mathrm{hm} . \% \mathrm{~S})$.

\section{Diskusia a závery}

Rudný výskyt U-Cu mineralizácie Spišská Teplica Vápenica - Vysová nikdy nebol popri skúmaných ložiskách tejto mineralizácie $v$ Dúbrave mineralogicky študovaný. Primárna mineralizácia $v$ permských pieskovcoch so zuhol'natenými zvyškami flóry je tvorená uraninitom a pyritom. Chalkopyrit a Cu-S fáza (digenit?, roxbyit?) tvoria inklúzie v klastickom fluórapatite a zirkóne. Zo supergénnych minerálov sú absolútne dominantné malachit a goethit (resp. limonit), menej zastúpené sú azurit, zálesít a barit. Iba ojedinele bol zistený fosfát pravdepodobne florencitovej skupiny a akantit.

Hoci zálesíit je vo svete značne rozšíreným mineráIom (93 lokalít; mindat.org), na Slovensku bol doposial' zistený jednako na študovanej lokalite a v druhom prípade na rudnom výskyte stratiformnej U-Cu mineralizácie v permských pieskovcoch Nižný Chmelienec v Nízkych Tatrách (Hoppanová 2020). Za zdroj časti Y, respektíve aj REE v zálesíite je možné považovat' akcesorické minerály hostitel'ských hornín zrudnenia: monazit-(Ce), fluórapatit a zirkón; ich chemické zloženie je ilustrované v tabul'kách 2 a 3 . Z nich najvyšší priemerný obsah Y $(2.70 \mathrm{hm}$. $\% \mathrm{Y}_{2} \mathrm{O}_{3}$ ) je v monazite-(Ce), nízke obsahy tohto prvku boli zistené vo fluórapatite (priem. $0.12 \mathrm{hm} . \% \mathrm{Y}_{2} \mathrm{O}_{3}$ ) a zirkóne (priem. 0.15 hm. \% $\mathrm{Y}_{2} \mathrm{O}_{3}$ ). Rojkovič (1975) predpokladá väzbu Y na zirkón a uránové minerály, na základe pozitívnej korelácie Y s U a Zr. V nemineralizovaných pieskovcoch uvádza priemerný obsah Y 19 ppm a v rudných šošovkách jeho výrazné zvýšenie (216 ppm). Monazit(Ce), fluórapatit a zirkón sa vyznačujú pomerne vysokou stabilitou a odolnost'ou voči zvetrávaniu, teda nemožno predpokladat', že podstatná čast' $Y$ v zálesíite pochádza práve z nich. Za hlavný zdroj Y je preto treba považovat' uraninit, v súlade $\mathrm{s}$ predpokladom Rojkoviča (I. c.), ktorý ovel'a l'ahšie podlahne zvetrávacím procesom, ako vyššie uvedené minerály. Dôveryhodnú WDS analýzu uraninitu zo Spišskej Teplice sa nepodarilo získat' kvôli malému rozmeru jeho zŕn, pórovitému povrchu a intímnemu prerastaniu sa s pyritom.

Napriek logickému očakávaniu, supergénne, uranylové minerály neboli v prípade Spišskej Teplice zistené. Obdobne, aj na ložiskách U rúd v Dúbrave sú supergénne U minerály zastúpené len vo vel'mi malej miere a v zlom vývoji (malé plošné rozšírenie na povrchu rúd, jemnozrnnost', hrúbka povlakov obyčajne pod $0.5 \mathrm{~mm}$ ). Ich relatívne bohatšie akumulácie sú skôr výnimočné. Tento fakt by bolo možné vysvetlit' samotným charakterom primárnej rudy. Mineralizácia je viazaná na pieskovce $s$ bohatým obsahom fragmentov zuhol'natenej flóry (obr. 2, 3). Priemerný obsah organického uhlíka sa v rudách pohybuje okolo $2.8 \mathrm{hm}$. \% (v extrémnych prípadoch aj $30-40 \mathrm{hm}$. $\%)$, zatial' čo $v$ nezrudnených pieskovcoch je priemerný obsah $\mathrm{C}_{\mathrm{ORG}}$ iba $0.15 \mathrm{hm}$. \%. Urán a $\mathrm{C}_{\mathrm{ORG}}$ vykazujú pozitívnu koreláciu s koeficientom $r=0.66$ (Rojkovič 1975; Roj-
Tabul'ka 2 Mikroanalýzy klastického monazitu-(Ce) (Mnz) a zirkónu (Zrn) zo Spišskej Teplice (Vápenica - Vysová)

\begin{tabular}{|c|c|c|c|c|}
\hline & 1 & 2 & 3 & $\begin{array}{r}4 \\
7 \mathrm{rn}\end{array}$ \\
\hline & Mnz & Mnz & Zrn & \\
\hline $\mathrm{CaO}$ & 0.84 & 0.84 & & \\
\hline $\mathrm{BaO}$ & 0.00 & 0.07 & 0.38 & 0.00 \\
\hline $\mathrm{MnO}$ & 0.01 & 0.07 & & \\
\hline $\mathrm{PbO}$ & 0.08 & 0.06 & & \\
\hline $\mathrm{Y}_{2} \mathrm{O}_{3}$ & 2.80 & 2.60 & 0.08 & 0.22 \\
\hline $\mathrm{La}_{2} \mathrm{O}_{3}$ & 14.36 & 14.84 & 0.00 & 0.03 \\
\hline $\mathrm{Ce}_{2} \mathrm{O}_{3}^{3}$ & 27.82 & 28.62 & & \\
\hline $\mathrm{Pr}_{2} \mathrm{O}_{3}$ & 2.85 & 3.09 & & \\
\hline $\mathrm{Nd}_{2} \mathrm{O}_{3}$ & 11.29 & 11.21 & & \\
\hline $\mathrm{Sm}_{2} \mathrm{O}_{3}$ & 1.61 & 1.63 & & \\
\hline $\mathrm{Eu}_{2} \mathrm{O}_{3}$ & 0.29 & 0.24 & & \\
\hline $\mathrm{Gd}_{2} \mathrm{O}_{3}^{3}$ & 1.01 & 1.22 & 0.07 & 0.00 \\
\hline $\mathrm{Tb}_{2} \mathrm{O}_{3}$ & 0.17 & 0.19 & & \\
\hline $\mathrm{Dy}_{2} \mathrm{O}_{3}$ & 0.70 & 0.88 & 0.00 & 0.12 \\
\hline $\mathrm{HO}_{2} \mathrm{O}_{3}$ & 0.00 & 0.08 & 0.03 & 0.00 \\
\hline $\mathrm{Er}_{2} \mathrm{O}_{3}$ & 0.18 & 0.23 & & \\
\hline $\mathrm{Tm}_{2} \mathrm{O}_{3}$ & 0.00 & 0.08 & & \\
\hline $\mathrm{Yb}_{2} \mathrm{O}_{3}$ & 0.00 & 0.11 & 0.00 & 0.04 \\
\hline $\mathrm{Lu}_{2} \mathrm{O}_{3}^{3}$ & 0.17 & 0.00 & 0.02 & 0.00 \\
\hline $\mathrm{TiO}_{2}$ & & & 0.12 & 0.03 \\
\hline $\mathrm{ZrO}_{2}^{2}$ & & & 63.05 & 63.16 \\
\hline $\mathrm{HfO}_{2}^{2}$ & & & 1.82 & 3.42 \\
\hline $\mathrm{ThO}_{2}^{2}$ & 3.89 & 3.71 & 0.01 & 0.00 \\
\hline $\mathrm{UO}_{2}{ }^{2}$ & 0.70 & 0.66 & 0.01 & 0.18 \\
\hline $\mathrm{SiO}_{2}$ & 0.41 & 0.36 & 33.36 & 33.02 \\
\hline $\mathrm{P}_{2} \mathrm{O}_{5}^{2}$ & 29.88 & 30.76 & 0.04 & 0.24 \\
\hline $\mathrm{As}_{2} \mathrm{O}_{5}$ & 0.06 & 0.01 & 0.03 & 0.07 \\
\hline $\mathrm{SO}_{3}$ & 0.02 & 0.03 & & \\
\hline$\Sigma \mathrm{hm} . \%$ & 99.13 & 101.58 & 99.00 & 100.52 \\
\hline
\end{tabular}

\begin{tabular}{|c|c|c|c|c|}
\hline \multicolumn{5}{|c|}{ kryštalochemické koeficienty } \\
\hline $\mathrm{Ca}$ & 0.035 & 0.034 & & \\
\hline $\mathrm{Ba}$ & 0.000 & 0.001 & 0.005 & 0.000 \\
\hline $\mathrm{Mn}$ & 0.000 & 0.002 & & \\
\hline $\mathrm{Pb}$ & 0.001 & 0.001 & & \\
\hline Y & 0.058 & 0.053 & 0.001 & 0.004 \\
\hline La & 0.207 & 0.209 & 0.000 & 0.000 \\
\hline $\mathrm{Ce}$ & 0.399 & 0.401 & & \\
\hline $\operatorname{Pr}$ & 0.041 & 0.043 & & \\
\hline $\mathrm{Nd}$ & 0.158 & 0.153 & & \\
\hline Sm & 0.022 & 0.021 & & \\
\hline Eu & 0.004 & 0.003 & & \\
\hline Gd & 0.013 & 0.015 & 0.001 & 0.000 \\
\hline $\mathrm{Tb}$ & 0.002 & 0.002 & & \\
\hline Dy & 0.009 & 0.011 & 0.000 & 0.001 \\
\hline Ho & 0.000 & 0.001 & 0.000 & 0.000 \\
\hline $\mathrm{Er}$ & 0.002 & 0.003 & & \\
\hline $\mathrm{Tm}$ & 0.000 & 0.001 & & \\
\hline $\mathrm{Yb}$ & 0.000 & 0.001 & 0.000 & 0.000 \\
\hline Lu & 0.002 & 0.000 & 0.000 & 0.000 \\
\hline $\mathrm{Ti}$ & & & 0.003 & 0.001 \\
\hline $\mathrm{Zr}$ & & & 0.947 & 0.943 \\
\hline $\mathrm{Hf}$ & & & 0.016 & 0.030 \\
\hline Th & 0.035 & 0.032 & 0.000 & 0.000 \\
\hline U & 0.006 & 0.006 & 0.000 & 0.001 \\
\hline Cat. & 0.993 & 0.992 & 0.973 & 0.981 \\
\hline $\mathrm{Si}$ & 0.016 & 0.014 & 1.028 & 1.012 \\
\hline $\mathrm{P}$ & 0.988 & 0.992 & 0.001 & 0.006 \\
\hline As & 0.001 & 0.000 & 0.001 & 0.001 \\
\hline S & 0.001 & 0.001 & & \\
\hline An. & 1.006 & 1.007 & 1.029 & 1.019 \\
\hline$Y+R E E$ & 0.916 & 0.917 & 0.002 & 0.006 \\
\hline
\end{tabular}

Empirické vzorce monazitu-(Ce) a zirkónu boli prepočítané na 4 kyslíky. 
Tabul'ka 3 Mikroanalýzy klastického fluórapatitu zo Spišskej Teplice (Vápenica - Vysová)

\begin{tabular}{|c|c|c|c|}
\hline & 1 & 2 & 3 \\
\hline $\mathrm{Na}_{2} \mathrm{O}$ & 0.00 & 0.18 & 0.01 \\
\hline $\mathrm{CaO}$ & 55.22 & 54.51 & 54.67 \\
\hline $\mathrm{SrO}$ & 0.16 & 0.09 & 0.01 \\
\hline $\mathrm{MnO}$ & 0.11 & 0.00 & 0.04 \\
\hline $\mathrm{FeO}$ & 0.06 & 0.00 & 0.05 \\
\hline $\mathrm{PbO}$ & 0.03 & 0.02 & 0.00 \\
\hline $\mathrm{Al}_{2} \mathrm{O}_{3}$ & 0.03 & 0.01 & 0.00 \\
\hline $\mathrm{Y}_{2} \mathrm{O}_{3}$ & 0.05 & 0.21 & 0.11 \\
\hline $\mathrm{La}_{2} \mathrm{O}_{3}$ & 0.02 & 0.03 & 0.02 \\
\hline $\mathrm{Ce}_{2} \mathrm{O}_{3}$ & 0.01 & 0.13 & 0.00 \\
\hline $\mathrm{Pr}_{2} \mathrm{O}_{3}^{3}$ & 0.07 & 0.00 & 0.03 \\
\hline $\mathrm{Nd}_{2} \mathrm{O}_{3}$ & 0.00 & 0.21 & 0.00 \\
\hline $\mathrm{Sm}_{2} \mathrm{O}_{3}$ & 0.01 & 0.05 & 0.00 \\
\hline $\mathrm{TiO}_{2}$ & 0.11 & 0.00 & 0.00 \\
\hline $\mathrm{ThO}_{2}$ & 0.00 & 0.10 & 0.00 \\
\hline $\mathrm{UO}_{2}{ }^{2}$ & 0.02 & 0.05 & 0.00 \\
\hline $\mathrm{SiO}_{2}$ & 0.03 & 0.05 & 0.04 \\
\hline $\mathrm{P}_{2} \mathrm{O}_{5}$ & 43.33 & 40.41 & 42.35 \\
\hline $\mathrm{SO}_{3}$ & 0.01 & 0.12 & 0.00 \\
\hline $\mathrm{F}$ & 3.63 & 4.02 & 3.60 \\
\hline $\mathrm{Cl}$ & 0.01 & 0.02 & 0.02 \\
\hline $\mathrm{H}_{2} \mathrm{O}^{*}$ & 0.18 & 0.00 & 0.13 \\
\hline $\mathrm{CO}_{2}{ }^{*}$ & 0.00 & 0.43 & 0.00 \\
\hline$\Sigma$ hm. $\%$ & 103.09 & 100.62 & 101.09 \\
\hline $\mathrm{F}=\mathrm{O}$ & -1.53 & -1.69 & -1.52 \\
\hline $\mathrm{Cl}=\mathrm{O}$ & -0.00 & -0.00 & -0.01 \\
\hline$\Sigma$ hm. \% & 101.56 & 98.93 & 99.57 \\
\hline
\end{tabular}

kryštalochemické koeficienty

\begin{tabular}{llll}
\hline $\mathrm{Na}$ & 0.000 & 0.030 & 0.002 \\
$\mathrm{Ca}$ & 4.891 & 5.016 & 4.938 \\
$\mathrm{Sr}$ & 0.008 & 0.004 & 0.001 \\
$\mathrm{Mn}$ & 0.008 & 0.000 & 0.003 \\
$\mathrm{Fe}$ & 0.004 & 0.000 & 0.004 \\
$\mathrm{~Pb}$ & 0.001 & 0.001 & 0.000 \\
$\mathrm{Al}$ & 0.003 & 0.001 & 0.000 \\
$\mathrm{Y}$ & 0.002 & 0.009 & 0.005 \\
$\mathrm{La}$ & 0.000 & 0.001 & 0.000 \\
$\mathrm{Ce}$ & 0.000 & 0.004 & 0.000 \\
$\mathrm{Pr}$ & 0.002 & 0.000 & 0.001 \\
$\mathrm{Nd}$ & 0.000 & 0.007 & 0.000 \\
$\mathrm{Sm}$ & 0.000 & 0.001 & 0.000 \\
$\mathrm{Ti}$ & 0.007 & 0.000 & 0.000 \\
$\mathrm{Th}$ & 0.000 & 0.002 & 0.000 \\
$\mathrm{U}$ & 0.000 & 0.001 & 0.000 \\
\hline$\Sigma \mathrm{A}$ & 4.927 & 5.077 & 4.953 \\
\hline $\mathrm{Si}$ & 0.002 & 0.004 & 0.003 \\
$\mathrm{P}$ & 3.032 & 2.938 & 3.022 \\
$\mathrm{~S}$ & 0.001 & 0.008 & 0.000 \\
$\mathrm{C}$ & 0.000 & 0.050 & 0.000 \\
\hline$\Sigma T$ & 3.035 & 3.000 & 3.026 \\
\hline $\mathrm{F}$ & 0.948 & 1.092 & 0.960 \\
$\mathrm{Cl}$ & 0.001 & 0.002 & 0.003 \\
$\mathrm{OH}$ & 0.051 & 0.000 & 0.036 \\
\hline$\Sigma X$ & 1.000 & 1.094 & 1.000 \\
\hline $\mathrm{Em}$ & $1.000 \mathrm{r}$ & &
\end{tabular}

Empirický vzorec fluórapatitu bol prepočítaný na 13 aniónov. $\mathrm{H}_{2} \mathrm{O}^{*}, \mathrm{CO}_{2}{ }^{*}$ - obsahy vypočítané na základe vyrovnania nábojov vo vzorci. kovič et al. 1992). V primárnych rudách vystupuje urán vo forme nemobilného $U^{4+}$ (uraninit, coffinit). Pri zvetrávaní $U$ rúd sa vplyvom rôznych faktorov (klíma, $\mathrm{pH}$ prostredia...) mení na $\cup^{6+}$, ktorý je naopak $v$ prírode mobilný. Urán tak migruje vo forme uranylového katiónu $\left(\mathrm{UO}_{2}{ }^{2+}\right)$ v rozpustných komplexných zlúčeninách, z ktorých najväčší význam majú karbonáty (Langmuir 1978). Organická hmota v sedimentoch predstavuje významnú geochemickú bariéru, kde dochádza $\mathrm{k}$ redukcii $\mathrm{U}^{6+}$ na $\mathrm{U}^{4+}$, $\mathrm{k}$ jeho imobilizácii a koncentrácii až do ložiskových akumulácií. Tento proces je však zložitejší a prebieha najmä dvoma spôsobmi. Prvým spôsobom je komplexácia (dehydrogenácia uhlia) kedy dochádza $\mathrm{k}$ naviazaniu $\mathrm{UO}_{2}{ }^{2+}$ na karboxylové funkčné skupiny organiky a k vzniku organických komplexov uranylu: $2 \mathrm{R}-\mathrm{COOH}+\mathrm{UO}_{2}{ }^{2+} \rightarrow \mathrm{RCOO}-\left(\mathrm{UO}_{2}\right)-\mathrm{OOCR}$ $+2 \mathrm{H}^{+}$(napr. Breger 1974; Munier-Lamy et al. 1986; Landais 1996). Druhý spôsob predstavuje priama redukcia $U^{6+}$ na $U^{4+}$, pri oxidácii organiky, dokázaná aj experimentálne (napr. Nakashima et al. 1984): $2(\mathrm{RH})+\mathrm{UO}_{2}{ }^{2+} \rightarrow 2 \mathrm{R}^{0}$ $+2 \mathrm{H}^{+}+\mathrm{UO}_{2}$ (uraninit). $\mathrm{K}$ vzniku uraninitu môže dôjst' aj deštrukciou prírodných organických komplexov uranylu $v$ starších infiltračných $U$ rudách počas ich termálneho prepracovania, kedy dochádza k redukcii uránu (Meunier et al. 1990). Pri zvetrávaní primárnych rúd v Dúbrave sa $z$ uraninitu a coffinitu uvol'ňuje katión $\mathrm{UO}_{2}{ }^{2+}$ do supergénnych roztokov (komplexy uranylu). Tieto roztoky sa však prakticky inned' dostávajú do kontaktu s fragmentmi zuhol'natenej flóry (zvlášt' $v$ prípade bohatých $U$ rúd), kde dochádza $\mathrm{k}$ viazaniu $\mathrm{UO}_{2}{ }^{2+}$ do organických komplexov uranylu (komplexácia). Menej pravdepodobným mechanizmom viazania/imobilizácie uránu je priama redukcia na organickú hmotu, nakol'ko $v$ tomto prípade ide o pomerne dlhodobý proces (Goldhaber et al. 1987; Spirakis 1996). Len pomerne malá čast' roztokov obsahujúcich $\mathrm{UO}_{2}{ }^{2+}$ sa nedostane do kontaktu s organikou, a práve z nich precipitujú supergénne uranylové minerály. Najbohatšie akumulácie supergénnych minerálov $U$ v Dúbrave sa nachádzajú práve na vzorkách bez, alebo s minimálnym obsahom makroskopicky viditel'nej organiky, v niektorých prípadoch dokonca na povrchu nezrudnených hornín. V prípade bohatých rúd s hojnými fragmentmi zuhol'natenej flóry dochádza k precipitácii uranylových minerálov dominantne na hostitel'skej hornine, zatial' čo na úlomkoch organickej hmoty sa tieto tvoria v obmedzenej miere, alebo sa vôbec netvoria (obr. 12).

\section{Pod'akovanie}

Tento príspevok mohol vzniknút' vd'aka finančnej podpore grantov VEGA 1/0237/18 a APVV-19-0065, tiež aj projektu ITMS 26210120024, spolufinancovaného zo zdrojov Európskeho fondu regionálneho rozvoja. Autori sú vel'mi vd'ační recenzentom Jiřímu Čejkovi a Martinovi Števkovi, ktorí svojimi postrehmi a pripomienkami prispeli k skvalitneniu manuskriptu.

\section{Literatúra}

Biely A, Beñuška P, Bezák V, Bujnovský A, Halouzka R, IvaNIČKA J, KoHÚt M, KLINEC A, LUKÁČIK E, MaglaY J, MIKO O, Pulec M, Putıš M, VozÁr J (1992) Geologická mapa Nízkych Tatier, $1: 50$ 000. ŠGÚDŠ Bratislava

Biely A, Bezák V, Bujnovský A, VozÁrová A, Klinec A, Miko O, Halouzka R, Vozár J, Beñuška P, Hanzel $V$, Kubeš $P$, LIŠČÁK P, LukÁČIK E, Maglay J, Molák B, Pulec M, Putıš M, SLAVKAY M (1997) Vysvetlivky ku geologickej mape Nízkych Tatier, 1: 50 000. 1-232, ŠGúDŠ Bratislava 
BREGER IA (1974) The role of organic matter in the accumulation of uranium: the organic geochemistry of the coal-uranium association. Proceedings book from symposium Formation of uranium ore deposits (Athens), 99-123. IAEA Vienna

Butı D, Rosı F, Brunettı BG, MILIANI C (2013) In-situ identification of copper-based green pigments on paintings and manuscripts by reflection FTIR. Anal Bioanal Chem 405: 2699-2711

Dostal J, VozÁr J, Keppie JD, Hovorka D (2003) Permian volcanism in the Central Western Carpathians (Slovakia): Basin-and-range type rifting in the southern Laurussian margin. Int $\mathrm{J}$ Earth Sci (Geol Rundsch) 92: $27-35$

EMSLEY J (1980) Very strong hydrogen bonding. Chem Soc Rev 9: 91-124

FARMER VC (1974) The infrared spectra of minerals. 1-539, Cambridge University Press, London

FERENC Š, KuRUc P (2015) Bane Sv. Alžbety - historický výskyt medených rúd pri Kravanoch (Spiš). Montanrevue 8(4): 6-7

FERENC Š, RoJkovič I (2001) Copper mineralization in the Permian basalts of the Hronicum Unit, Slovakia. Geolines 13: 22-27

Fusán O, Bystrický J, franko O, Chmelík F, llavský J, KamenickÝ L, Kullman E, LuKNIŠ M, MatĚJKa A (1963) Vysvetlivky $\mathrm{k}$ prehl'adnej geologickej mape ČSSR (1 : 200 000), list Vysoké Tatry. 1-215, Geofond, Bratislava

GAO J, YUAN X (2020) Vibrational investigation of pressure -induced phase transitions of hydroxycarbonate malachite $\mathrm{Cu}_{2}\left(\mathrm{CO}_{3}\right)(\mathrm{OH})_{2}$. Minerals: 10, 277, 14

Goldhaber MB, Hemingway BS, Mohagheghi A, Reynolds RI, NORTHROP HR (1987) Origin of coffinite in sedimentary rocks by a sequential adsorption-reduction mechanism. Bull Miner 110: 131-144

HopPANOVÁ E (2020) Supergénne alterácie stratiformnej U-Cu mineralizácie $v$ mladšom paleozoiku hronika Kozích chrbtov a Nízkych Tatier. MS, diplomová práca, FPV UMB Banská Bystrica.

Lafuente B, Downs RT, Yang H, Stone N (2015) The power of databases: the RRUFF project. In: Armbruster T, Danisi RM (eds.): Highlights in Mineralogical Crystallography, 1-30. W. De Gruyter Berlin

LIBOWITZKY E (1999) Correlation of O-H stretching frequencies and $\mathrm{O}-\mathrm{H} \cdots \mathrm{O}$ hydrogen bond lenghts in minerals. Monatsh Chem 130: 1047-1059

LANDAIS P (1996) Organic geochemistry of sedimentary uranium ore deposits. Ore Geol Rev 11: 33-51

LANGMUIR D (1978) Uranium solution-mineral equilibria at low temperatures with application to sedimentary ore deposits. Geochim Cosmochim Acta 42: 547-569

Maglay J, Halouzka R, Bañacký V, Pristaš J, Janočko J (1999) Neotektonická mapa Slovenska, 1:500 000. ŠGÚDŠ Bratislava

Meunier JD, Landais P, Pagel M (1990) Experimental evidence of uraninite formation from diagenesis of uranium-rich organic matter. Geochim Cosmochim Acta 54: 809-817

Miliani C, Rosi F, Daveri A, Brunetti BG (2012) Reflection infrared spectroscopy for the non-invasive in situ study of artists'pigments. Appl Phys A 106: 295-307

MindAT. Prístup 20. 7. 2020 na adrese https://www.mindat. org/min-7026.html
Morrison SM, Domanik KJ, Origlieri MJ, Downs R (2013) Agardite- $(\mathrm{Y}), \mathrm{Cu}_{6}^{2+} \mathrm{Y}\left(\mathrm{AsO}_{4}\right)_{3}(\mathrm{OH})_{6} \cdot 3 \mathrm{H}_{2} \mathrm{O}$. Acta Cryst E 69: i61-i62

Munier-Lamy C, Adrian P, Berthelin J, Rouiller J (1986) Comparison of binding abilities of fulvic and humic acids extracted from recent marine sediments with $\mathrm{UO}_{2}{ }^{2+}$. Org Geochem 9: 285-292

Nakashima S, Disnar JR, Perruchot A, Trichet J (1984) Experimental study of mechanisms of fixation and reduction of uranium by sedimentary organic matter under diagenetic hydrothermal conditions. Geochim Cosmochim Acta 48: 2321-2329

NovotNÝ L, BADÁR J (1971) Stratigrafia, sedimentológia a zrudnenie mladšieho paleozoika severovýchodnej časti Nízkych Tatier. Miner Slov 3: 23-36

Olmi F, Sabelli C, Trostı FR (1991) A contribution to the crystal chemistry of mixite group minerals from Sardinia (Italy). N Jb Miner, Mh (1991): 487-499

OlšAVSKÝ M, FeRENC Š (2002) Character of Permian volcanosedimentary sequences (Malužiná Formation) of the Hronicum unit at the NE part of Nízke Tatry Mts. Geol. Carpath., special issue, 53 (only on CD-ROM, 2002), Proceedings of the XVII Congress of Carpathian-Balkan Association, Bratislava, 53/part 0

PlÁšIL J, HLoušEK J, Kasatkin AV (2014) Pozoruhodný výskyt metat'ujamunitu a minerálů mixitové skupiny na Dušní žíle (Geister), Jáchymov (Česká republika). Bull mineral-petrolog Odd Nár Muz (Praha) 22: 215220

PlášIL J, SEJKora J, ČEJKa J, ŠKoda R, GoliÁš V (2009) Supergene mineralization of the Medvědín uranium deposit, Krkonoše Mountains, Czech Republic. J Geosci 54: 15-56

Ricci C, Miliani C, Brunetti BG, Sgammellotti A (2006) Non-invasive identification of surface materials on marble artifacts with fiber optic mid-FTIR reflectance spectroscopy. Talanta 69: 1221-1226

RoJkovıč I (1975) Geochemical characterization of U-Cu - $\mathrm{Pb}$ mineralization in the Permian of the Choč Nappe in the Vikartovský chrbát area. Geol Zbor Geol Carpath 26: 105-114

RoJkovıč I (1997) Uranium mineralization in Slovakia. 1-117, Comenius University, Bratislava

RoJkovič I, Franců J, ČÁsLAVSKÝ J (1992) Association of organic matter with uranium mineralization in the Permian sandstones of the Western Carpathians. Geol Carpath 43: 27-34

Salvadó N, Butí S, Aranda MAG, Pradell T (2014) New insights on blue pigment used in $15^{\text {th }}$ century paintings by synchrotron radiaton-based micro-FTIR and XRD. Anal Meth 6: 3610-3621

SEJKORA J, ŠKÁCHA P, ČEJKA J (2019) REE-bohatý zálesíit z Bělovsi u Náchoda (Česká republika). Bull Mineral Petrolog 27: 297-303

SCHMIDT M, LUTZ HD (1993) Hydrogen bonding in basic copper salts: a spectroscopic study of malachite, $\mathrm{Cu}_{2}(\mathrm{OH})_{2} \mathrm{CO}_{3}$, and brochantite, $\mathrm{Cu}_{4}(\mathrm{OH})_{6} \mathrm{SO}_{4}$. Phys Chem Miner 20: 27-32

SpectraBase. Prístup 25. 6. 2020 na adrese http:// spectrabase.com/spectrum/ENIrYngNX61

SPIRAKIS CS (1996) The roles of organic matter in the formation of uranium deposits in sedimentary rocks. Ore Geol Rev 11: 53-69 
Stoilova D, KoleVa V, VassileVa V (2002) Infrared study of some synthetic phases of malachite $\left(\mathrm{Cu}_{2}(\mathrm{OH})_{2} \mathrm{CO}_{3}\right)$ hydrozincite $\left(\mathrm{Zn}_{5}(\mathrm{OH})_{6}\left(\mathrm{CO}_{3}\right)_{2}\right)$ series. Spectr Acta Part A 58: 2051-2059

TuLIS J, Novotný L (1998) Zhodnotenie geologických prác na $U$ rudy $v$ mladšom paleozoiku hronika $v$ severnej časti Nízkych Tatier a Kozích chrbtov. MS, archív ŠGÚDŠ - Geofond Bratislava P 82752

VozÁR J (1977) Magmatické horniny tholeitickej série $\checkmark$ perme chočského príkrovu Západných Karpát. Miner Slov 9: 241-258
VoZÁr J, SPIŠIAK J, VozÁrovÁ A, BAZARNIK J, KRÁl' J (2015) Geochemistry and $\mathrm{Sr}$, Nd isotopic composition of the Hronic Upper Paleozoic basic rocks (Western Carpathians, Slovakia). Geol Carpath 66: 3-17

VozÁrovÁ A, VozÁr J (1988) Late Paleozoic in West Carpathians. 1-314, Geol Inst of D. Štúr, Bratislava

WISE WS (1978) Parnauite and goudeyite, two new copper arsenate minerals from the Majuba Hill Mine, Pershing County, Nevada. Amer Miner 63: 704-708 